\title{
Obras rústicas e ornamentos: os artífices e a técnica da rocaille para jardins e parques urbanos no Brasil entre o final do século XIX e o início do XX
}

Rustic works and ornaments: craftsmen and rocailles in gardens and urban parks in Brazil between the end of the nineteenth century and the beginning of the twentieth

\section{CRISTIANE MARIA MAGALHÃES'}

Centro Superior de Ensino e Pesquisa de Machado / Machado, MG, Brasil

RESUMO: Este artigo aborda a difusão, no Sudeste do Brasil, do trabalho dos rocailleurs e dos cascateiros e de suas obras, as rocailles. Esses ornatos eram confeccionados em cimento armado, entre o final do século XIX e as duas primeiras décadas do século XX, para jardins e parques de estilo paysager. $\bigcirc$ repertório das obras em rocaille incluía pontes, bordas de repuxos, tanques e lagos, cascatas e grutas artificiais, miradouros, coretos, bancos, quiosques, mesas e caramanchões. Tais artefatos eram, em sua grande maioria, feitos para imitar as texturas dos troncos das árvores, dos bambus, de cipós, a feição dos conjuntos rochosos, de pequenos insetos, entre outros elementos do universo mineral e do orgânico. Quanto à delimitação temporal, identificou-se que o apogeu da constituição desses ornatos em cimento armado para jardins, parques públicos, residências das famílias abastadas nos centros urbanos e também nas fazendas ocorreu entre 1870 e a década de 1920. Nesse mesmo período, reclames nos periódicos, notadamente os do Rio de Janeiro, anunciavam serviços de jardineiros, rocailleurs e de cascateiros especialistas na arte e na técnica de construir cascatas, grutas e demais obras em cimento armado ao gosto da época. Os trabalhos de estrangeiros como o chef rocailleur francês Paul Villon e o cascateiro português Francisco da Silva Reis serão aqui examinados, tomados como expoentes e extremos de um processo histórico que teve seu início, apogeu e declínio durante o período mencionado.

PALAVRAS-CHAVE: Brasil. Virada do século XIX-XX. Rocailleurs. Cascateiros. Jardim paysager. Pitoresco. Jardim romântico.

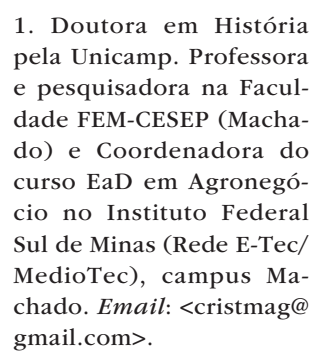
gmail.com>. 
2. Ver Ernest Gombrich (1998, p. 329).
ABSTRACT: This article deals with the proliferation of rocailleurs and cascateiros and their works, the rocailles, in the southeast of Brazil. These adornments were made from reinforced concrete between the end of the nineteenth century and the first two decades of the twentieth century, for gardens and parks in the landscaped paysager style. The repertoire of rocaille works included bridges, fountain borders, ponds, waterfalls and artificial caves, viewpoints, bandstands, benches, kiosks, tables and arbors. These artifacts were mostly made to mimic the textures of tree trunks, bamboos, vines, the shape of rocky clumps and small insects, among other organic and mineral elements. The highpoint of these reinforced concrete embellishments for gardens, public parks, and the homes of wealthy families in the urban centers and also in farms occurred between 1870 and the 1920s. During that time, advertisements in newspapers, notably those in Rio de Janeiro, announced the services of gardeners, rocailleurs, and cascateiros, specialists in the art and technique of building waterfalls, caves, and other fashionable works in reinforced concrete. This essay examines the work of foreigners like the French chef rocailleur Paul Villon and the Portuguese cascateiro Francisco da Silva, taken as examples of a historical process that had its beginning, apogee, and decline during the aforementioned period.

KEYWORDS: Brazil, turn of the nineteenth century, rocailleurs, cascateiros, paysager gardens, picturesque, romantic garden

\section{INTRODUÇÃO}

Imagens e descrições de recantos de jardins e parques urbanos ocidentais criados no século XIX nos remetem aos ideais oitocentistas do sublime e do belo, associados ao romantismo e à noção de pitoresco, que se opunham aos preceitos clássicos da arte, da arquitetura e do paisagismo barroco. A estética pitoresca ou pinturesca - idêntica ou que remete à ideia da pintura - designava tipos de construções como castelos, ruínas e pontes, e também paisagens contendo barcos à vela, moinhos de vento, certas montanhas e florestas. ${ }^{2}$ Os elementos identificados como pitorescos reportavam a um sentimento de naturalidade e se constituíam de determinadas representações simbolicamente delineadas segundo valores românticos dos séculos XVIII e XIX, inglês e francês, respectivamente. Segundo esse ideal de beleza, a natureza era sublime e deveria ser recriada para contemplação e admiração. Dessa forma, os jardins do período romântico podiam possuir em sua composição combinações de elementos formais habituais com outros exóticos, tais como o pagode, as cascatas e as grutas, os pavilhões mouriscos e góticos, 
mausoléus, simulações de ruínas antigas e templos, bem como bosques sombreados e riachos - tudo isso disposto em terrenos irregulares. Essa cenografia romântica pretendia criar no espectador a ideia de uma paisagem natural, cuidadosamente recortada e organizada pelo homem. No Brasil, o ideal pitoresco romântico do oitocentos, embora numa clara associação ao jardim burguês do segundo Império francês, será adaptado às condições naturais do país e à disponibilidade de recursos financeiros para sua urdidura em recantos ajardinados públicos urbanos.

Os jardins públicos urbanos criados segundo aqueles preceitos, primeiramente na Inglaterra e reelaborados na Paris de Haussmann, privilegiavam a sinuosidade orgânica dos caminhos, as árvores frondosas formando pequenos bosques junto a extensos gramados, assim como pergolados, construções similares a ruínas e pontes, a constituição de lagos, ilhas, riachos, cascatas artificiais, além de ornatos confeccionados em cimento armado, as rocailles. Esses ornamentos se compunham de elementos decorativos para jardins e parques do tipo rústico, confeccionados à mão por habilidosos artesãos, em que as texturas feitas na argamassa imitavam madeira, pedra, pequenos insetos, conformavam grutas, guarda-corpos de pontes, cascatas, bancos, etc.

Imigrantes aportados no Brasil na segunda metade do século XIX tiveram atuação fundamental na recriação de cenários pitorescos nos jardins, praças e parques do país. Analisando o contexto semelhante da presença dos rocailleurs estrangeiros na Argentina, Michel Racine considerou que a imigração de grandes massas de artífices europeus, por volta de 1880, foi fundamental para a implantação do estilo do jardim burguês francês, o jardin paysager, e de sua disseminação no país. ${ }^{3}$ No Brasil, esse processo se iniciou num período anterior, em torno de 1860-1870, sendo que grande parte desses profissionais se fixou no Rio de Janeiro, a corte imperial do país.

Naquele tempo, os periódicos faziam circular na capital brasileira as notícias das exposições universais, dos feitos industriais e, na mesma medida, enfatizavam as grandes reformas urbanísticas e os melhoramentos sanitaristas e de embelezamento ocorridos nas principais capitais europeias. Descrições dos parques urbanos franceses com suas grandes cascatas artificiais aguçavam o interesse das elites e dos administradores em modernizar a cidade do Rio de Janeiro. E era nesses mesmos jornais e revistas que os artífices estrangeiros anunciavam os seus serviços e iam divulgando suas habilidades associadas ao jardim paysager.

Os princípios urbanísticos em circulação na segunda metade do século XIX, balizados no paradigma parisiense estabelecido pela reforma haussmanniana, intencionavam uma cidade que deveria ser bela e planejada, além de higiênica. $\bigcirc$ historiador Lewis Mumford ${ }^{4}$ frisa que esse século foi, antes de tudo, um período
3. Ver Michel Racine (2001, p. 123).

4. Ver Lewis Mumford (1991, p. 484). 
5. Cf. Eduardo Laemmert e Henrique Laemmert (1862, p. 313-314). de consciência da função higiênica e sanitária dos espaços livres. Os novos espaços verdes das capitais europeias foram tomados como símbolos de higiene, beleza e purificação. Portanto, era mister na corte do Brasil e nas capitais provinciais a conformação de jardins, passeios e parques públicos no lugar dos antigos charcos, pátios desnudos e nos entroncamentos das avenidas em urbanização.

$\bigcirc$ "jardim mais moderno", como anunciado nos periódicos e revistas de horticultura, era aclamado e reelaborado aqui nos trópicos. Uma matéria do Almanak Laemmert, de 1862, refere-se a essa nova concepção paisagística presente já na reforma do Passeio Público do Rio de Janeiro, empreendida por Francisco Fialho e pelo botânico Auguste François Marie Glaziou (1 828-1906) em 1861. Foi por causa desse trabalho, e a convite de Fialho, que Glaziou fixou residência no Brasil:

Essa planta representa um jardim cognominado inglês ou paisagista, gênero atualmente adotado nos países de mais adiantada civilização, por sua natural e graciosa singeleza, pois nele se esconde a arte sob as mais belas formas da natureza, que é o seu mestre e modelo depois de tirar o maior partido possível do terreno em que opera, e dos pitorescos sítios circunvizinhos, dos quais como se apossa, pelo efeito das perspectivas, com o fim de alargar os horizontes e seus términos. [...] $\bigcirc$ Passeio Público é uma miniatura do jardim paisagista, mas miniatura de mão de mestre. ${ }^{5}$

A primeira versão do Passeio Público carioca, criado em fins do século XVIII, seguia a orientação geométrica da tradição clássica presente nos jardins maneiristas e barrocos italianos, bem como nos franceses da era bourbônica. $\bigcirc$ repertório ornamental incluía esculturas de mármore com inspirações clássicas, os rebuscados e simétricos parterrres, as escadarias e os terraços, além da vegetação cuidadosamente podada pela técnica da topiaria. Já na reforma empreendida em 1861, contudo, a inspiração para a recriação e a remodelação desse jardim foi proveniente da estética pitoresca do jardim paysager, à maneira dos squares e parques parisienses.

A reformulação do Passeio Público converteu-se num exemplo difusor que seria retomado por jardineiros e pelo próprio Glaziou em diversos jardins públicos e privados no Rio de Janeiro e nas cidades serranas fluminenses. Interpretações locais desses jardins paysagers - que aqui eram denominados comumente de jardins românticos, jardins ao gosto inglês ou somente jardins ingleses e, ainda, de jardins mais modernos - não dispensaram o uso de faianças portuguesas (vasos, estátuas e bustos), mas adotaram com grande ênfase, sobretudo nos jardins públicos, os ornamentos e utilitários em ferro fundido (postes, estátuas, chafarizes, coretos e chalés), além de mobiliário em rocaille confeccionado em cimento armado. 
A rocaille tinha como principal característica falsear elementos naturais, tais como rochedos, troncos de árvores, grutas e cascatas, que aqui eram aludidas como obras d'arte ou obras rústicas. A plasticidade das argamassas de cimento era favorável à elaboração de texturas variadas e, ainda, era possível receber pigmentos, que proporcionavam um aspecto mais natural às obras. Os jardins e parques brasileiros que adotaram o estilo paysager entre a segunda metade do século XIX e as duas primeiras décadas do XX foram ornamentados com esses equipamentos decorativos. A criação desses cenários pitorescos demandava profissionais capacitados, conhecedores da técnica dos rocailleurs, pelo que alguns especialistas europeus começaram a emigrar para o Brasil em busca de oportunidades de trabalho.

Ao aportar no Brasil ao longo do oitocentos, os artífices estrangeiros possuíam muitas expectativas, mas a maioria não gozava de renome. As redes sociais e profissionais iam se fazendo no processo de trabalho, como foram os casos bem conhecidos de Glaziou, de Ludwig Riedel (1790-1861) e de Paul Villon (1841-1905). Uma parcela considerável deles, contudo, viveu sem notoriedade durante sua estada nos trópicos. Outros tiveram certo reconhecimento na sua época, mas passaram para a história sem expressividade, como foram os casos de John Tyndale, Arsênio Puttemans, dos jardineiros e horticultores Jean-Baptiste Binot, Garnier, G. Krieger e Augustin Mallemont. Em algumas situações, o apagamento da memória desses profissionais estrangeiros se fez tão fortemente que seus trabalhos foram atribuídos, no século XX, a outros imigrantes de maior prestígio. ${ }^{\circ}$ Referimo-nos, por exemplo, ao sucedido com o parque e os jardins da quinta do comendador Mariano Procópio Ferreira Lage, em Juiz de Fora (MG), ainda hoje um dos mais preservados e representativos parques privados no estilo paysager do século XIX. Pesquisas apontam que o arquiteto e engenheiro agrimensor italiano Carlos Camillo Carlini, entre outros anônimos, foi um dos responsáveis pela organização da quinta do comendador, finalizada no ano de 1863. A autoria do projeto, contudo, foi por muito tempo atribuída a Glaziou.

Nesse contexto de rara consagração e notoriedade mesmo para os paisagistas, pouco se sabe sobre os artífices estrangeiros que elaboraram a ornamentação utilizada nos jardins projetados por Glaziou, Riedel ou Villon, incluindo-se entre eles os rocailleurs que realizavam as grutas e ornamentos de cimento, que eram uma das marcas distintivas desses projetos paisagísticos.

\section{A TÉCNICA E SEUS ARTíFICES}

No entendimento de Inês El-Jaick Andrade, o avanço tecnológico do século XVIII possibilitou o desenvolvimento da técnica da rocaille, em virtude das
6. Os nomes de estrangeiros eram muitas vezes abrasileirados, o que dificulta, em certa medida, as pesquisas sobre esses profissionais estrangeiros ligados à renovação dos parques e jardins na segunda metade do oitocentos brasileiro. Ludwig Riedel se transformou em Luiz Riedel; Paul Villon, em Paulo Villon e, às vezes, Paulo Villan, Willon ou Paulo Vileon; Auguste Glaziou era nomeado de Augusto Glaziou, entre outras variações para os mesmos nomes. 
7. Ver Inês El-Jaick Andrade (2014, p. 262).

8. Ver Nelson Porto Ribeiro (2014, p. 7).

9. Ver H. Chevrel (1846, p. 34).

10. Ver François-Marie de Marsy (1746, p. 170).

11. Ibidem.

12. Ver Eugène Sageret (1903).

13. Ver Michel Racine (2001, pp. 93-94). descobertas científicas da geologia e da engenharia na Europa, em especial na Inglaterra. Esses avanços revelaram propriedades de diferentes materiais, entre estes o cimento hidráulico (1756) e o cimento portland (1824). É atribuído ao jardineiro e horticultor francês Joseph Monier (1823-1906), responsável pelo jardim das Tuileries, em Paris, o emprego da técnica do cimento armado em ornamentos para jardins e parques.? Ele próprio se autorreferiu, em 1846, como horticulteur-rocailleur. Monier uniu armações de ferro, cerâmicas e pedras à argamassa composta por cimento para executar resistentes vasos de flores, reservatórios e pontes. Essa técnica patenteada por Monier foi denominada de cimento armado. A nomenclatura "concreto armado" teria surgido décadas depois, a partir de 1892, ${ }^{8}$ e se vulgarizado no século XX. O Bulletin de la Société d'Horticulture de Cherbourg, de 1846, menciona a descoberta de Monier e o designa como horticulteur-rocailleur. ${ }^{9}$

O vocábulo rocailleur aparece no Dictionnaire abregé de peinture et d'architecture, de François-Marie de Marsy, datado de 1746. ${ }^{10}$ Nesse dicionário, rocaille aparece como: "construction de rocaille, grotte de rocaille, colonne de rocaille", sendo "un assemblage de coquillages de pierres brutes, de pétrifications. Qui imitent tantôt des rochers, tantôt des grottes, tantôt des colonnes. L'ouvrier qui travaille aux rocailles, s'appelle Rocailleur". " Em geral, rocailleur indicava "constructeur de chalets, kiosques, ponts, rivières, bassins, spéc. de travaux en ciment armé". ${ }^{12}$

Michel Racine escreveu que o termo "rocailleur", ligado a nomes de profissionais em anuários franceses, apareceu em 1845, no anuário parisiense DidotBottin, designando três nomes. Em 1848, mais dois rocailleurs anunciaram seus serviços em Nantes, no Annuaire général de la Loire-Inférieure. Entre 1850 e 1860, as fábricas de cimento se multiplicaram, segundo Racine, e, junto com elas, cada vez mais os rocailleurs recorriam ao novo material. Os artesãos ligados ao ofício de rocailleur aumentam rapidamente, principalmente nas grandes cidades e nas regiões produtoras de cimento. Nesse sentido, a execução das grandes rocailles do Parc des Buttes-Chaumont (1866 a 1869), em Paris, é paradigmática. Racine identificou que o termo podia possuir variações de um profissional a outro ou em anuários distintos: "rocailleur", "rustiqueur", "spécialiste-rocailleur", "rocailleur-paysagiste", "cimentierrocailleur", "artiste-rocailleur", "rocailleur-artiste en ciment", "cimentier-naturiste", "rocailleur-cimentier", ou simplesmente "cimentier" eram designações para o mesmo tipo de profissional. ${ }^{13}$ Podiam ser conhecidos também como "horticulteurs-rocailleurs" e "maçons-cimentiers". Em inglês, esses profissionais podiam ser nomeados como rock-workers e, em espanhol, como artesanos de las rocallas.

Em Portugal, cascateiro, de modo similar a rocailleur na França, foi designado pelo Diccionario technico e historico de pintura, esculptura, architectura 
e gravura, de Francisco de Assis Rodrigues (1801-1877), como: "s. m. o artezano, ou oficial que trabalha em cascatas". ${ }^{14}$ Em Portugal, ainda hoje, o termo cascateiro aplica-se aos artesãos que participam da tradição popular das miniaturas de cascatas no Conselho de Vila Nova de Gaia, realizada por barristas conhecidos como Cascateiros de Avintes. ${ }^{15}$

A acepção do rocailleur chegou ao Brasil dos séculos XIX e XX como o construtor de cascatas, grutas e demais obras d'arte artificiais com imitação de minerais e vegetais. Aqui, os profissionais que detinham o mesmo ofício também ficaram conhecidos como cascateiros ou, na década de 1890, pedreiros rochistas. ${ }^{16}$

As primeiras referências documentadas a respeito da utilização da técnica da rocaille em jardins públicos no Brasil são relativas às reformulações paisagísticas realizadas nos jardins paysagers do período imperial. Ornamentos desse material foram adotados no Campo de Santana carioca (1880), também conhecido como Parque da Aclamação, atual Praça da República, segundo projeto concebido por Auguste Glaziou, e no Jardim da Luz (1879), em São Paulo. É a partir dessas obras do final da década de 1870 e até de outras, realizadas na década de 1920, que observamos o apogeu dos anúncios, nos periódicos, de profissionais autodenominados "cascateiros" e construtores de cascatas para jardins, atuação que oscilava entre a condição de técnico e de artista.

Na França, Édouard André, em seu célebre tratado L'art des Jardins, referiuse aos trabalhos de rocailleurs dentro desta ambivalência: "En régie, le prix moyen d'un bon ouvrier rocailleur, un peu artiste, est de 10 francs par jour à Paris. Cet homme choisit des aides, qui sont payés au prix ordinaire des manceuvresmaçons". ${ }^{17}$ André sinalizava uma falsa dicotomia que vai acompanhar o trabalho dos rocailleurs nos séculos XIX e XX: a do operário que era também considerado um artista burguês e popular. Michel Racine, ao refletir sobre esse estatuto dúbio, compreende que se tratava da união entre o artesão e o artista, pois os rocailleurs se posicionavam numa ligação entre dois mundos, entre o homem-artesão e o trabalho mecanizado, entre o saber propagado pelas academias e liceus de artes e ofícios e o aprendizado popular: "Tenir les artisans pour des artistes contrevient durement à la notion de division du travail qui, au nom de l'efficacité technique, exclut tout art de la vie quotidienne de l'ouvrier". ${ }^{18}$

Assim como na França, os cascateiros que atuaram no Brasil requeriam para si um estatuto diferenciado dos demais artífices e artesãos de sua época. Em 1895, no jornal Diário de Notícias, do Rio de Janeiro, publicou-se a seguinte matéria: "O conhecido artista francês Garnier, um dos mais antigos cascateiros de nosso país, declarou pessoalmente ao presidente [da Sociedade Nacional de Aclimação]
14. Cf. Francisco de Assis Rodrigues (1875).

15. Ver Ignácio Nuno Pignatelli (2016). A arquiteta paisagista Teresa Marques (2009) refere-se ao termo rocailleur, mencionado num documento de seu país em 1902, para designar operários que executariam trabalho em cimento armado para jardins. A autora ressalta, porém, ter localizado apenas uma única designação a rocail leur nos documentos pesquisados. Ver Teresa Marques (2009, p. 297). O termo cascateiro, embora apareça num dicionário de Portugal do século XIX, não foi localizado pela pesquisadora para designar os técnicos que construíam cascatas para jardins naquele país

16. Pessoal empregado na Inspetoria de Matas e Jardins em 1893.

17. Cf. Édouard André (1879, p. 510), grifo nosso.

18. Cf. Michel Racine (2001, p. 146). 
19. Cf. Diário de Notícias (1895).

20. Cf. O Pharol (1891).

21. Cf. Jornal da Tarde (1879, p. 1) achar-se à disposição da sociedade para auxiliá-la nos trabalhos de sua especialidade". ${ }^{19}$ De igual modo, o cascateiro João Ribeiro Bastos, que atuava em Juiz de Fora, anunciava que: "(...) também encarrega-se de trabalhos em cascatas, lagos e todo e qualquer trabalho que pertença à arte de cascateiro. Rua Halfeld, n. 39. Juiz de Fora". ${ }^{20}$ Outros anúncios ligavam semelhantemente o ofício de cascateiro ao fazer artístico.

No Brasil, os primeiros rocailleurs nem sempre podem ter seus nomes recuperados, e disso a obra do Jardim da Luz paulistano é exemplo. Em 1879, o presidente da província de São Paulo, Laurindo Abelardo de Brito, mandou construir um reservatório edificado na forma de um grande rochedo com gruta e estalactites e uma cascata no Jardim da Luz (Figuras 1 e 2), além de outras obras de embelezamento, como pontilhões rústicos, lago e ilha artificial. A solução atendia a questões estéticas e resolvia o problema de abastecimento de água do jardim, que persistia havia décadas:

As obras começaram no dia 21 de julho e terminaram-se no dia 21 de novembro próximo findo, isto é, foram feitas no curto espaço de 4 meses. Constam elas: (...) $3^{a}$. De um esplêndido reservatório de distribuição de 28 metros cúbicos de capacidade, cuja base forma uma linda gruta e o escoadouro uma cascata de 5 metros de altura. (...) 10 $10^{a}$. Enfim de uma restauração geral do jardim, pedregulhamento das ruas, etc. ${ }^{21}$

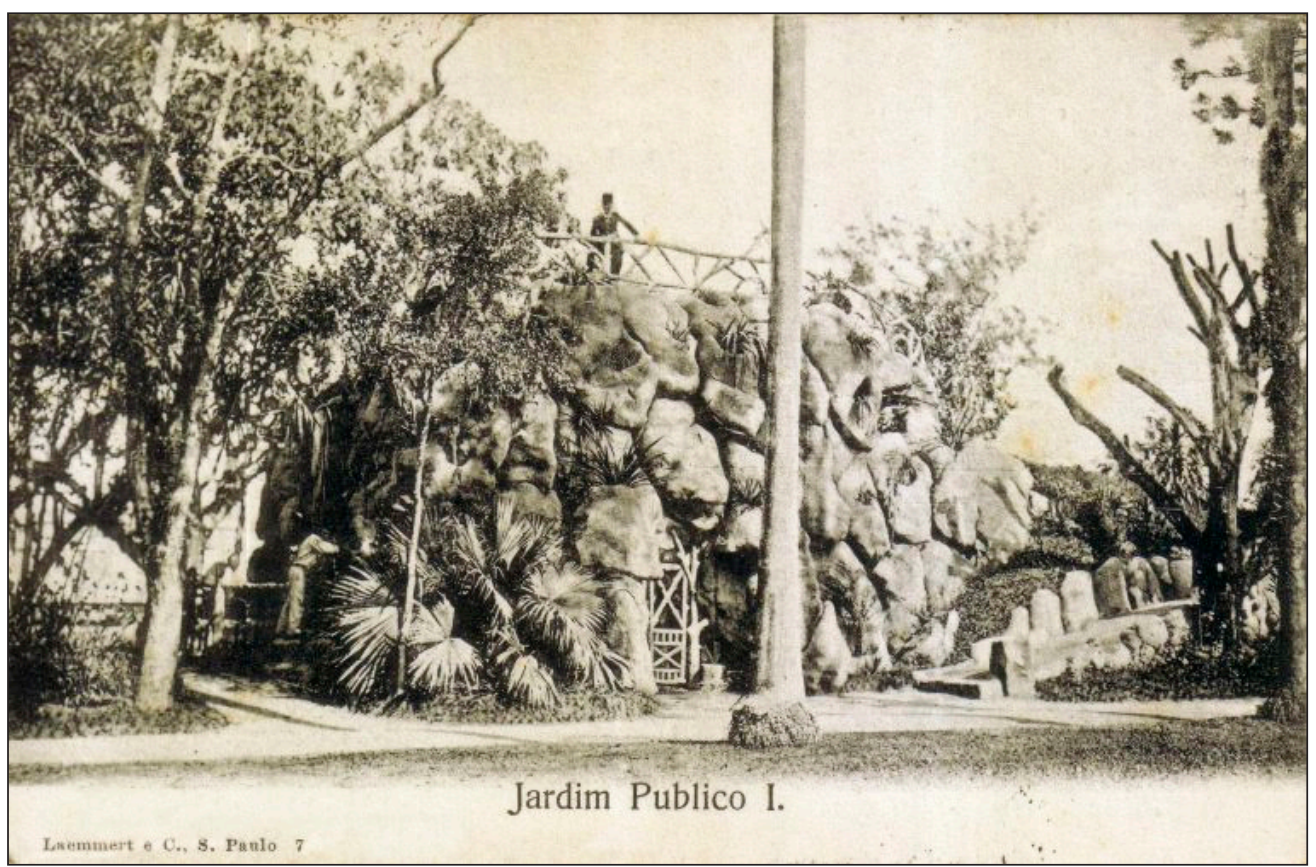

Figura 1 - Gruta com mirante no Jardim da Luz, mandada construir por Abelardo de Brito, em 1879. A gruta armazenava água para todo o parque. Cartão-postal sem data. Laemmert \& c. 
Antônio Bernardo Quartim era o inspetor geral dos jardins à época, e os engenheiros responsáveis pela obra de canalização no jardim foram Carlos Hermann Rohe e Eusébio Stevaux, autor do projeto. Não há menção ao técnico que realizou a gruta em cimento.

Uma outra ocorrência paulistana, a fonte do Largo de Palácio (1 886), foi realizada pelo mestre de obras italiano Serafim Corso, ligeiramente inspirada na fonte de Saint-Michel (Paris, 1856-1860) e na fonte do Palácio de Longchamp (Marselha, 1862-1869). Dessa última fonte, Corso pode ter retirado a referência formal da estátua sobre uma gruta. Além disso, também utilizou falseamento de pedras e guarda-corpos com imitação de troncos em cimento. ${ }^{22}$

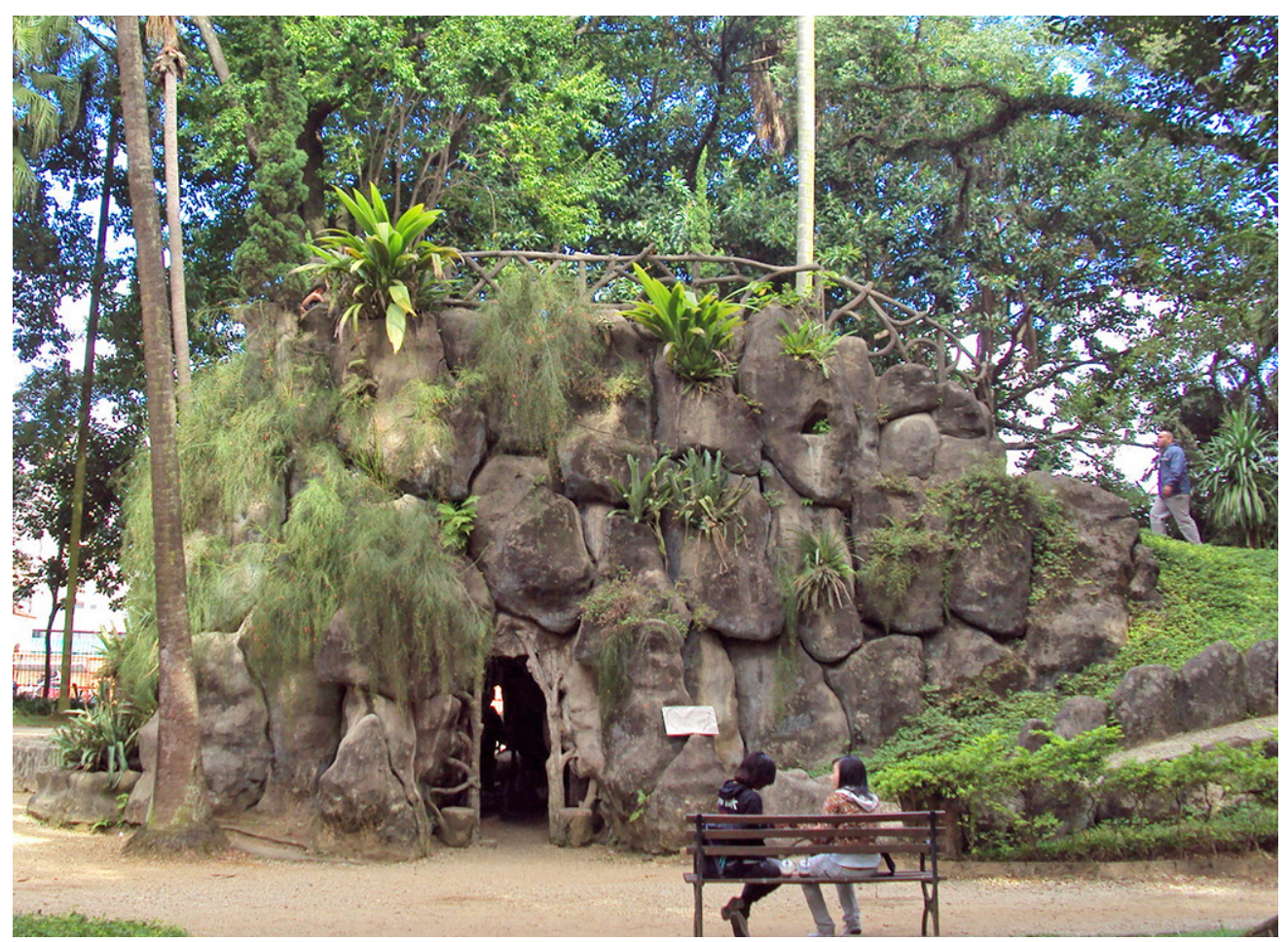

Figura 2 - Gruta com mirante no Jardim da Luz. Fotografia de Cristiane Magalhães, 2017.

Na mesma época, o francês Auguste Glaziou realizava, no Campo de Santana, um projeto tecnicamente ousado, numa extensa área de 146.400 m2 situada na região central da capital do Império. Por ocasião do início de sua construção, em 1874, o termo rocailleur foi utilizado num anúncio em que se fazia referência ao francês Paul Villon. Posteriormente, essa palavra desaparece de todas as fontes consultadas. Paul Villon é referido nos anos e décadas seguintes como paisagista, décorateur-pépiniériste, agricultor, jardineiro-
22. Ver Eudes Campos (1997, p. 268,922$)$. 
23. As informações familiares a respeito de Paul Villon foram fornecidas por seu sobrinho trineto, Victor Ribeiro Villon. Registro sinceros agradecimentos por sua generosidade e diálogo.

24. Nascido em Roybon, Departamento do Isère, França, em 19 de julho de 1841. Era o segundo dos oito filhos do casal André Villon e Constance Meunier.

25. Ver declaração de Paul Villon por ocasião de seu casamento ("Depoimento do Justificante ", Paul Villon, 1 fevereiro de 1884, Arquivo da Cúria do Rio de Janeiro).

26. Minas Gerais (1897).

27. A grafia correta para os nomes dos anunciantes seria Paul Villon e Augustin Mallemont. Emilio Wittig era horticultor no Rio de Janeiro na segunda metade do século XIX. Augustin Mallemont (1839-1899) era casado com Marie (1853-1929), irmã de Paul Villon, e trabalhou como jardineiro-chefe da Imperial Quinta da Boa Vista na década de 1880. A partir de 1893 atuou como jardineiro-chefe dos jardins públicos do Rio de Janeiro na Inspetoria de Matas e Jardins, ao lado de Glaziou, como inspetor geral. Ver Almanak... (1894-1899).

28. Cópia da carta e informações cedidas por Victor Villon. Os originais estão em posse dos descendentes de Piotr Gaston Kleniewski.

paisagista, empresário (ele abriu e administrou um parque e um restaurante na avenida Paulista) e arquiteto-paisagista, demonstrando seu ampliado campo de atuação profissional no Brasil.

\section{PAUL VILLON: DE CHEF ROCAILLEUR A ARQUITETO PAISAGISTA}

Paul Vincent Villon 23 foi um dos principais jardineiros paisagistas e rocailleurs a atuar no Brasil entre a década de 1870 e 1905. ${ }^{24}$ Villon mudou-se da França para o Brasil aos 24 anos, conforme consta em seu registro de casamento. ${ }^{25}$ Trabalhou ao lado de Auguste Glaziou nas reformas dos jardins e parques do Rio de Janeiro, até ser reconhecido e se firmar individualmente como paisagista de renome. Antes de vir para o Brasil, teria trabalhado quatro anos no estabelecimento de Meunier e Rocher Frères, em Grenoble, que desenvolvia de forma inovadora a horticultura e a arboricultura. ${ }^{26}$

Um dos primeiros registros das atividades de Paul Villon no Brasil é uma autodenominação como rocailleur. Anúncios publicados em periódicos do Rio de Janeiro (Figura 3) revelaram que Paul Villon, junto com seu cunhado Augustin Mallemont e Emilio Wittig, ${ }^{27}$ fazia cascatas à imitação de Roland (de Marselha) e Rocheford (da Bélgica). Paul Villon era o rocailleur e paisagista responsável pelas obras. Na figura 3, é possível visualizar um dos anúncios. Ainda na década de 1870, uma correspondência entre Elisa Kleniewski e seu irmão Piotr Gaston Kleniewski informa que Paul Villon era chef-rocailleur na Quinta Imperial de São Cristóvão. ${ }^{28}$

\section{Esplendidas maravilhas !}

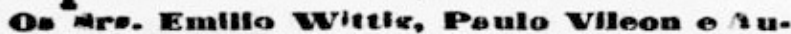

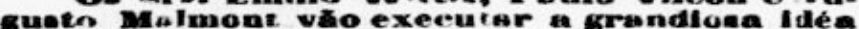

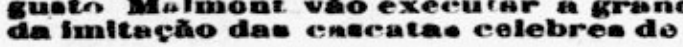

IOINAND (DE MARSELHA) $\mathbf{z}$ ROGRIPTOPT

(IDA IELCRCA)

ostudo expresenmente felto pelo dietincto ro-

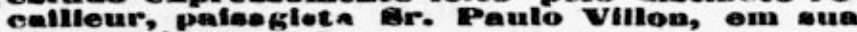
ulesma visgem a Gurupu.
Figura 3 - Anúncio do Jornal do Commercio de domingo, 25 de janeiro de 1874. 
Onúncio e a atuação de Paul Villon como rocailleur, ofício que executou durante toda a vida profissional no Brasil, mesmo que, posteriormente à década de 1870, tenha assumido qualificações mais elevadas nos projetos para jardins e parques, relacionam-no ao tempo da ascensão desse ofício na França. ${ }^{29}$ Não foi por acaso, portanto, que Villon se deslocou de Marselha à Bélgica para conhecer as obras mencionadas, que inspirariam sua atividade como rocailleur.

É provável que essa especialização técnica no ofício de rocailleur tenha sido o diferencial de Paul Villon em relação aos outros jardineiros e horticultores estrangeiros que viviam no Brasil e o cartão de visitas para o trabalho ao lado de Auguste Glaziou no Campo de Santana e na Quinta da Boa Vista. A construção do jardim do Campo de Santana ocorreu entre 1873 e 1880. Nesse grande parque público urbano, Glaziou introduziu peças de ferro provenientes da fundição Val D'Osne, de Haute-Marne, além do cenário criado com pedras artificiais com imitação de falésias, grutas, quedas d'água, um conjunto rochoso, guardas de pontes com imitação de troncos de árvores, pequenas construções e ruínas, além de lagos, caminhos de linhas circulares e importante conjunto arbóreo cultivado no viveiro da Quinta da Boa Vista.

Como chef rocailleur, Paul Villon ficou encarregado da execução das obras em cimento armado do Campo de Santana. ${ }^{30}$ Aquele era um trabalho técnico muito específico em hidráulica e engenharia civil para fazer funcionar uma cascata artificial num rochedo também artificial com material durável em meio ao movimento de águas (Figura 4). Decerto, Glaziou não possuía conhecimentos específicos para executar as construções de cascatas artificiais e conjuntos rochosos à maneira das rocailles francesas, como as existentes em Paris, em Marselha e em outras cidades ao redor da capital francesa, feitas num período próximo. É compreensível que tenha contratado profissionais especializados, como o caso de Paul Villon. $\bigcirc$ desenho e a disposição das rocailles no Campo de Santana, todavia, são de Glaziou.

Em matéria publicada pelo jornal $\bigcirc$ Apóstolo, de 29 de junho de 1879, há a descrição com pormenores das obras de Paul Villon no Campo de Santana. Essa descrição oferece um panorama da grandiosidade dos trabalhos em rocaille feitos na ocasião.

(...) as pontes rústicas, feitas de cimento e imitando troncos de árvores, são desenhadas com muita observação do natural e basta que a ação do tempo passe por elas mais alguns meses para que a ilusão seja completa, para que todos vejam no trabalho artificial troncos de árvores verdadeiras. (...). A grande cascała que só daqui a alguns anos se poderá ver em todo o seu resplendor é uma imponente massa de rochedos disposta com muita arte e que representa bem a majestade agreste da natureza do Brasil. Dentro de uma grande gruta onde se acham imitados com suma perfeição diversos grupos de estalactites e esta-
29. Ver Michel Racine (2001).

30. Ver July D. (1880). No Rio de Janeiro, o cimento era conhecido e comercializado desde meados do século XIX, como nos atestam os anúncios dos irmãos Ennes, comerciantes de cimento Portland, ver Eduardo Laemmert e Henrique Laemmert (1864, p. 49). A Revista do Instituto Polytechinco Brasileiro faz referências ao beton ou concreto na confecção de paralepípedo em sua edição n. 2 , de 1868 , ao mencionar a construção do quebra-mar do porto de Marselha. Nas edições posteriores, foram publicadas, periodicamente, reportagens sobre o uso desse material em algumas cidades, como no cais da alfândega do Porto (1872) e nas docas de Nova Iorque (1873). O Diário do Rio de Janeiro de 3 de setembro de 1869 veiculou a notícia de que a diretoria de obras públicas do Rio de Janeiro havia autorizado a encomenda de cem toneladas métricas de cimento especial para a fabricação do concreto (beton monolithe), a fim de ser o mesmo concreto ensaiado na construção de pontes e cais no Rio de Janeiro. 
31. Cf. O Apóstolo (1879), grifos nossos. lagmites, de onde, mais tarde, deve pingar água, dando assim à caverna o aspecto de obra da natureza. Desta grande gruta sobe-se, por diferentes caminhos, para a parte superior da cascata, deparando-se, na subida, com os mais caprichosos recessos, (...) o ingresso e saída da gruta efetua-se por cima dos troncos artificiais ou por sobre grandes pedras que de longe nem sequer indicam que é um caminho preparado para esse fim.

Em todo o jardim se encontram grupos de pedras e de troncos e não há um desses grupos, segundo nos informam, que não tenha sido previamente copiado da natureza em diferentes pontos da nossa bahia ou nas proximidades da capital.

O plano geral do jardim do campo da Acclamação é, como todos sabem, do Sr. Glaziou; os trabalhos de arte, como pontes, grupos de troncos e de pedras e a grande cascata, do Sr. Paulo Villon, e o ajardinamento, do Sr. Garnier e outros de que ignoramos os nomes.

Este jardim, logo que seja terminado, ficará uma obra monumental no seu gênero e que honrará não só a capital do Brasil como os governos e artistas que para a sua realização concorreram. ${ }^{31}$

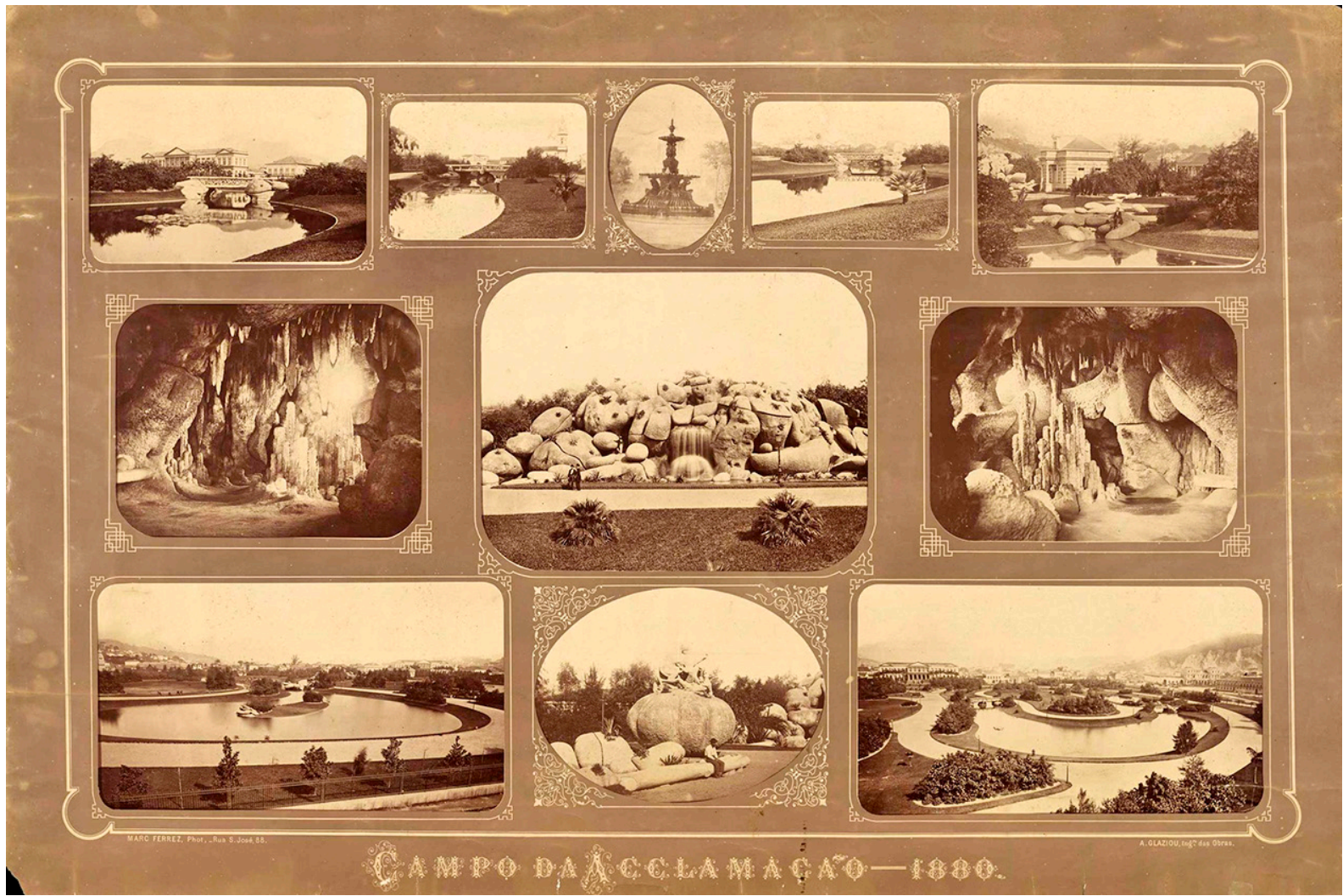

Figura 4 - Campo de Santana em imagens de 1880, de Marc Ferrez, mostrando os caminhos sinuosos e as obras em cimento armado modeladas por Paul Villon, com a gruta, o lago, a ponte, a cascata e o mirante. Acervo da Biblioteca Nacional, Rio de Janeiro. 
material das pontes construídas à época foi composto de ferro, pedra, argila, areia, saibro e óleo de baleia. ${ }^{32}$ Paul Villon e Glaziou teriam empregado, ainda, "matacões de granito" e cimento. ${ }^{33}$ Em correspondência à Diretoria da Secretaria de Estado e Negócios do Império, Glaziou escreveu, à época da feitura do Campo de Santana, que as construções rústicas deviam ser feitas de cimento, tijolo e ferro. ${ }^{34}$ Noutra correspondência, informava que não seria necessária a aquisição de grande quantidade de cimento, pois este deveria ser utilizado fresco para não perder sua faculdade de cristalização e que o material não poderia ser falso ou avariado pela umidade. Por esses motivos, devia-se comprar pequenas quantidades por vez. ${ }^{35}$

Os periódicos relataram com entusiasmo a inauguração e as obras constantes no Campo de Santana. Era um jardim realmente notável. A Revista Illustrada, inclusive, no seu número 223, de 1880, trouxe uma litografia em tamanho ampliado, mostrando em destaque apenas os trabalhos em rocaille (reprodução da imagem na figura 5).
32. Ver Celica Isaura Fernandes Belém et al. (1980, p. 413).

33. Cf. Mephistopheles, ano 2 , n. 55 (1874, p. 3 ).

34. Correspondência de 10 de maio de 1873; ver Carlos Terra (2000, p. 136).

35. Correspondência de 29 de maio de 1875; ver Carlos Terra (2000, p. 137).

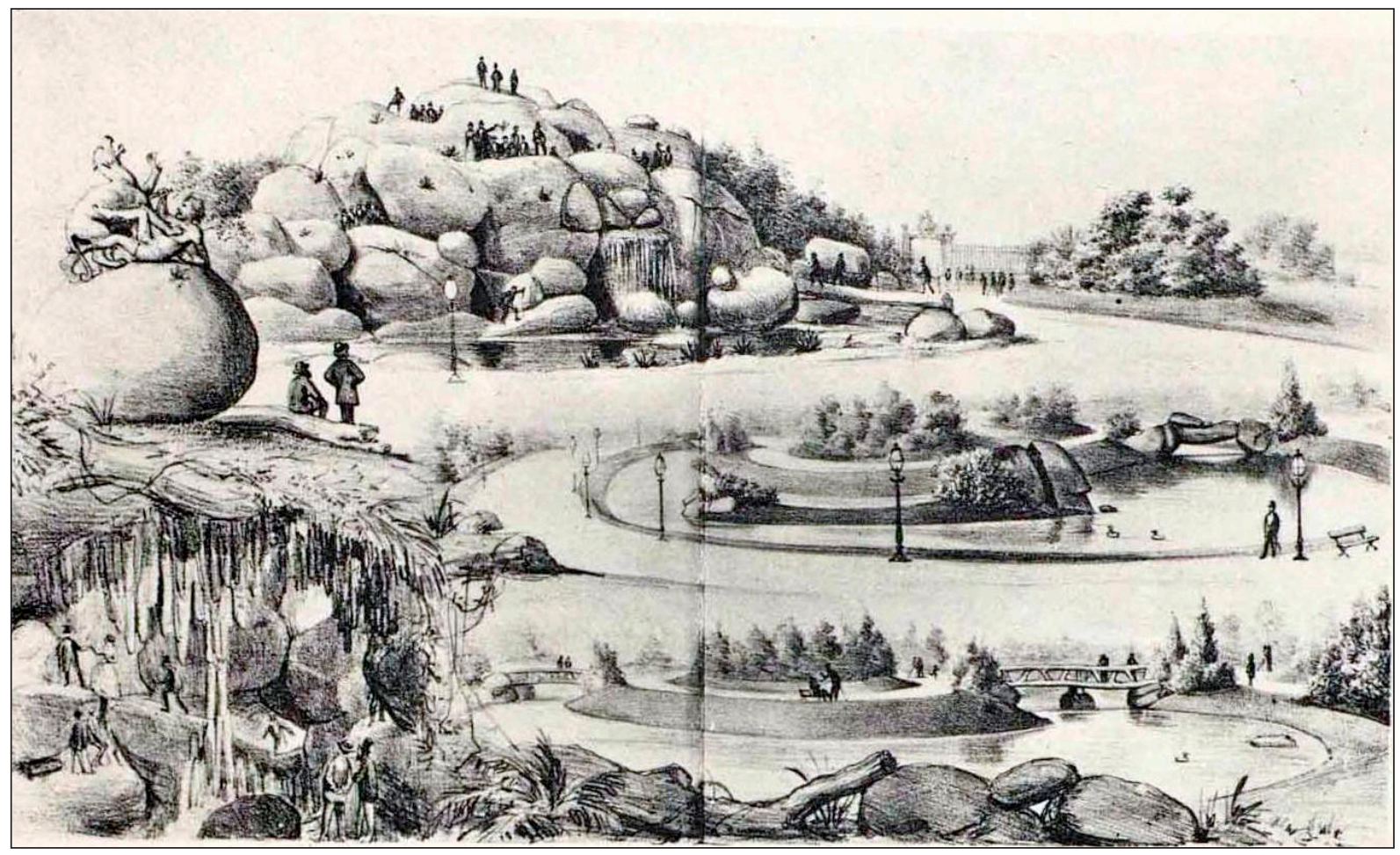

Figura 5 - Litografia de Angelo Agostini. Jardim do Campo de Santana. Fonte: Revista Illustrada, n. 223, 1880, p. 4. Acervo da Biblioteca Nacional, Rio de Janeiro. 
36. Cf. July D. (1880, p. 2).

37. Ver Minas Geraes (1897, p. 5).

38. Ver Jornal do Commercio $(1897$, p. 1).
Na edição anterior à publicação dessa imagem, a Revista Illustrada havia dado ênfase ao conjunto em rocaille do Campo de Santana:

As pontes e a grande cascata são obras de arte do Sr. Paul Villon que incontestavelmente dão um imenso realce ao jardim, quebrando-the a monotonia. (...) ○ Sr. Paul Villon muito concorreu também para o embelezamento do jardim com seus importantes trabalhos. A admiração que estes produziram no público é a melhor recompensa que podia ter o seu auto. ${ }^{36}$

Para além das atividades como rocailleur, Paul Villon foi se transformando, na prática, em arquiteto paisagista, manifestando a sua versatilidade e a variedade de atividades às quais se dedicou em torno da criação de parques e jardins. relato mais extenso que possui traços da biografia de Paul Villon é um artigo publicado no jornal Minas Geraes, de 23 de outubro de 1897, que tratou da construção do Parque Municipal de Belo Horizonte. Esse artigo foi utilizado como fonte para autores do século XX que fizeram referências a Paul Villon. No entanto, imprecisões quanto às informações ali constantes puderam ser verificadas. Em linhas gerais, porém, é possível traçar o percurso profissional de Villon, que, de chef rocailleur, tornou-se um paisagista, a partir daquele relato. $\bigcirc$ artigo refere-se a ele como o executor dos trabalhos do Parque da Aclamação e Quinta da Boa Vista. Havia restaurado, ainda, o parque do Palácio do Catete e construído os jardins da fazenda do Gavião, pertencente ao conde de Nova Friburgo. ${ }^{37}$ Todas essas obras foram executadas no estado do Rio de Janeiro.

Em 1896, a edificação e os jardins do Palácio do Catete, no Rio de Janeiro, foram restaurados para sediar a Presidência da República. Paul Villon foi contratado para realizar o tratamento paisagístico no parque do palácio e construiu um mirante em forma de rochedo encimando uma gruta e cascata. Um pequeno lago circunda o conjunto em rocaille. $O$ jornal $O$ Paiz, de 30 de maio de 1896, noticiou a reforma do parque do Palácio do Catete: "A restauração do Parque está confiada ao architecto paizagista Paul Villon, autor e executor do grande parque em construção na nova capital de Minas". O engenheiro Aarão Reis esteve à frente da restauração do Palácio do Catete, em 1896, e teria conhecido Paul Villon a partir do projeto para o Parque Municipal de Belo Horizonte, cujas obras ocorriam na mesma ocasião.

Na cidade de São Paulo, Paul Villon dedicou-se a um empreendimento maior, de cunho privado. Em 1892, construiu um parque e restaurante na avenida Paulista, que foi nomeado Parque Villon. Trata-se do atual Parque Trianon - Tenente Siqueira Campos, projetado e administrado por Paul Villon. Em 1897, o parque era referenciado como Parque Paulista e não mais Parque Villon ${ }^{38}$ e, em 1907, a Câmara de São Paulo solicitava orçamentos para a aquisição dos terrenos, a fim 
de transformar o parque privado em parque público. ${ }^{39} \bigcirc$ parque se manteve como propriedade particular até 1910, quando o prefeito Barão de Duprat adquiriu os terrenos do parque e do belvedere. A partir de projeto de Ramos de Azevedo, a nova configuração do parque foi inaugurada em 1916.

Em rocaille, há relato da existência de caramanchões rústicos no parque, à época de Villon. ${ }^{40}$ Em imagens do início do século XX, visualiza-se que existiam ali também bancos de cimento armado fingindo madeira, além de um chafariz ainda hoje existente, que forma um pequeno lago circular no seu entorno. O lago possui as bordas em rocaille imitando pedras. No projeto do parque constava que deveria haver "ribeiros, kiosques, conchas, rochedos e cascatas, pavilhão de música, ponte rústica, em uma palavra, todos os recursos da arte moderna", ${ }^{41}$ ou seja, uma profusão de obras em rocaille à maneira da época, não concretizadas.

sucesso dos trabalhos de Paul Villon no Rio de Janeiro, ao lado de Glaziou, e no projeto do parque e restaurante da avenida Paulista, em São Paulo, certamente contribuiu para o convite de criação de um grande parque público urbano na nova capital de Minas Gerais. Em novembro de 1894, Paul Villon apresentou a Aarão Reis, um dos responsáveis pela construção da capital de Minas, a planta para um grande parque urbano. ${ }^{42}$ Naquele mesmo ano, Villon tinha iniciado a criação de dois viveiros em Belo Horizonte, um para a floricultura e outro para o plantio de árvores indígenas e exóticas para atender à arborização do parque e das ruas, praças e avenidas da nova capital de Minas Gerais. ${ }^{43}$ Os viveiros localizavam-se no sítio Bolina de Baixo, e Villon era auxiliado por Alexis Morim. ${ }^{44}$ Ao longo da vida, Villon ia acumulando as profissões de rocailleur, horticultor, idealizador e gestor de parques e jardins. ${ }^{45}$

parque público foi inaugurado ainda inacabado, em setembro de 1897. Inspirado no padrão paysager francês, tanto na forma quanto nos equipamentos, o projeto grandioso de Paul Villon foi executado apenas em parte (Figura 6), da mesma maneira como havia acontecido com o parque paulista. Projetado para ser um jardim público monumental na nova capital de Minas, estavam previstos a construção de um cassino, de onde sairia uma cascata de seis metros de altura, e de um teatro, um restaurante, velódromo e observatório meteorológico, além de pavilhões e outras obras em rocaille, não concretizadas. A planta da figura 6 apresenta os grandes conjuntos em rocaille que deveriam ter sido construídos no parque. A despeito de as obras não terem sido realizadas na integralidade, esse foi um dos mais importantes projetos paisagísticos de Paul Villon no Brasil, em termos de conceito de parque público urbano e moderno. Em rocaille, existiram no parque algumas pontes; uma delas pode ser vista na figura 7 .
39. Ver O Commercio de São Paulo (1907).

40. Ver Ernani da Silva Bruno (1953, p. 1.229).

41. Cf. Rosa Grena Kliass (1993, p. 144).

42. Ver Minas Geraes (1894b, p. 2).

43. Ver Comissão Construtora da Nova Capital de Minas (1895, p. 17).

44. Ver Minas Geraes (1894a).

45. Em 6 de junho de 1895 , Villon foi nomeado oficialmente, pela Comissão Construtora da Nova Capital de Minas Gerais, como "architecto jardineiro" do parque, para acompanhamento da execução das obras e de gestão. Cf. Comissão... (2016). 


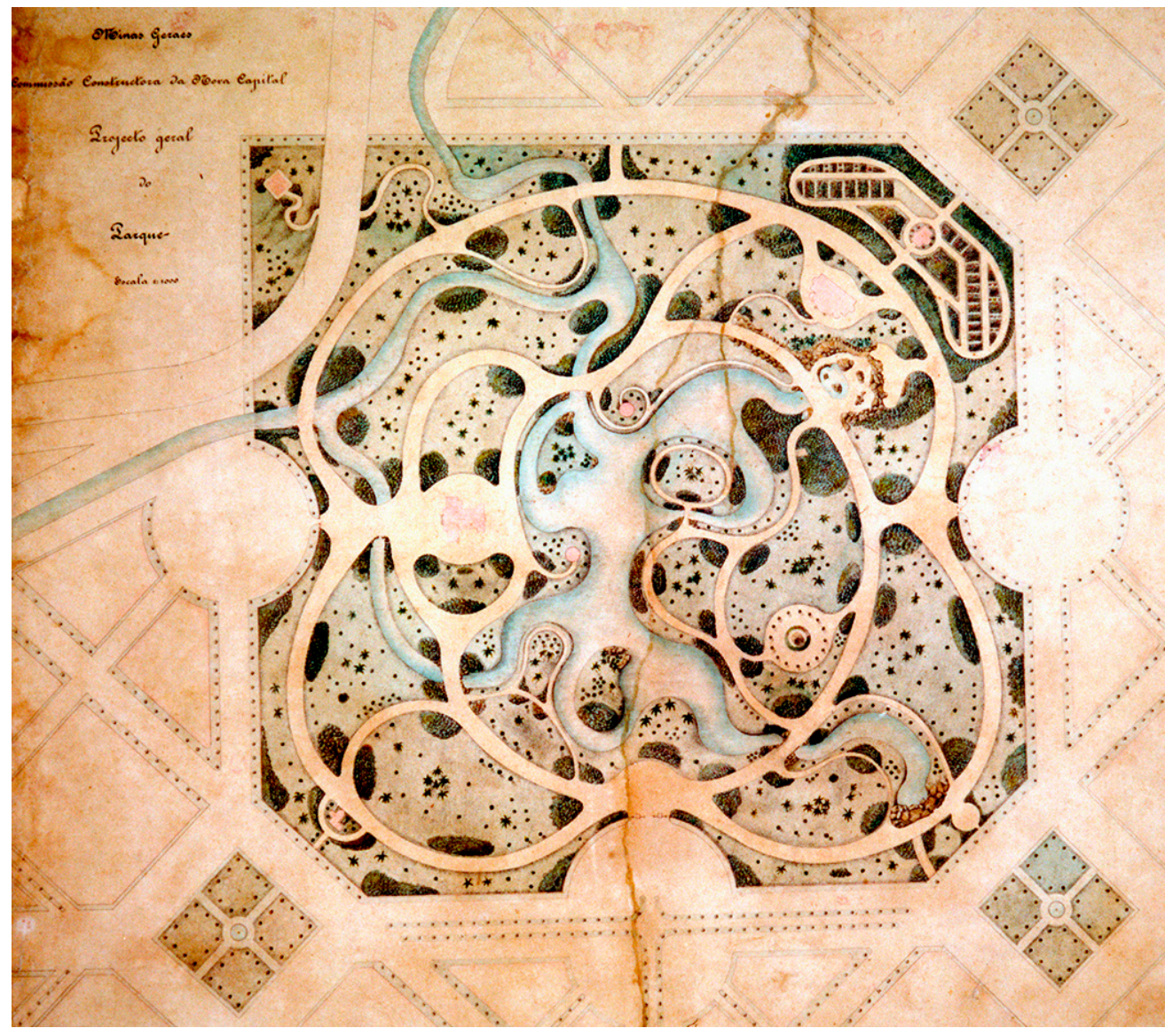

Figura 6 - Planta de Paul Villon para o Parque $\mathrm{Mu}$ nicipal de Belo Horizonte, 1894. Há grandes conjuntos em rocailles previstos para ser executados e que podem ser visualizados nesta planta. Acervo da Comissão Construtora Capital. Fonte: <https:// goo.gl/tpT8OP>. Acesso em: 7 jul. 2017.

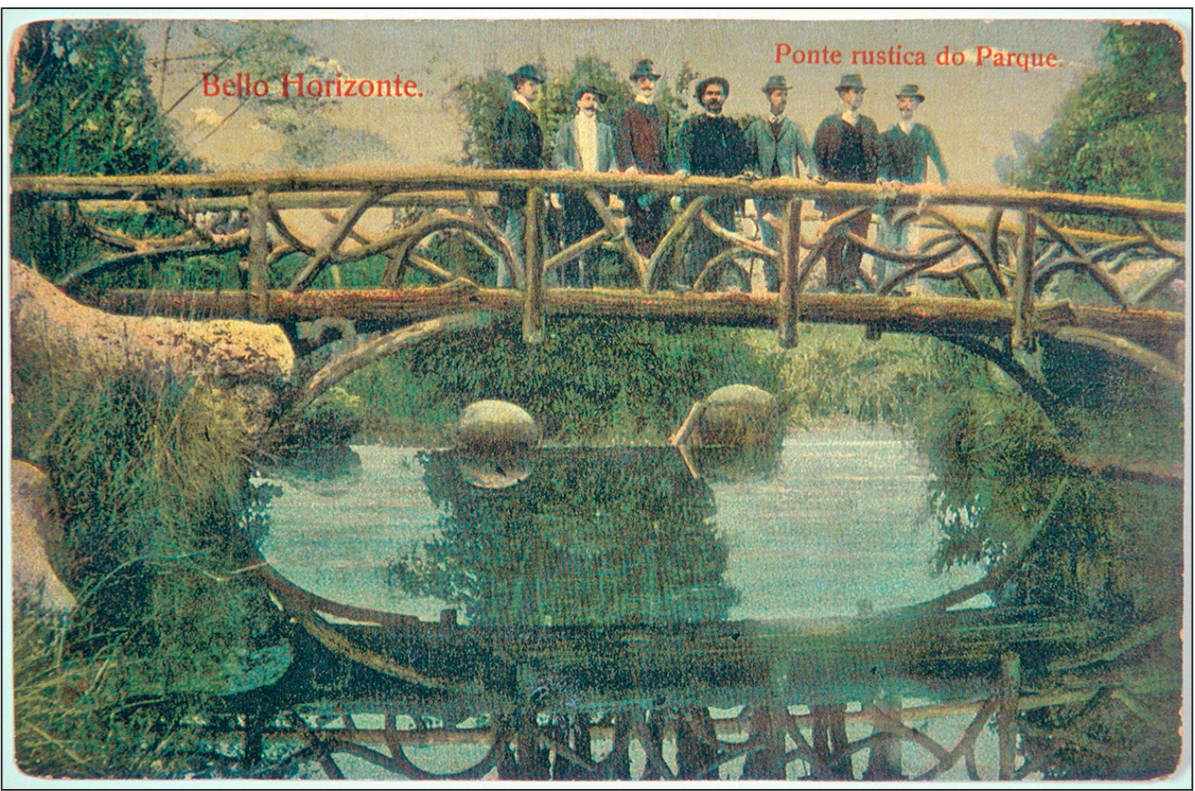

Figura 7 - Cartão-postal da ponte rústica do Parque Municipal de Belo Horizonte, início do séc. XX. Edição Casa Abílio. Acervo Museu Histórico Abílio Barreto (MHAB). 
Em Belo Horizonte, Villon foi responsável, também, pelos jardins do Palácio Presidencial ou Palácio da Liberdade. O ajardinamento ocorreu em dezembro de 1898 e o contrato que previa a execução das obras d'arte daquele jardim foi assinado em julho de 1899. ${ }^{46}$ Nos jardins privados do Palácio da Liberdade, Villon construiu, em rocaille, uma gruta artificial encimada por um coreto, com um pequeno lago envolvendo todo o conjunto escultórico. ${ }^{47}$

Outro projeto importante é atribuído a Paul Villon em Belo Horizonte. Entre 1903 e 1904, o prefeito Francisco Bressane contratou um projeto para o ajardinamento da praça da Liberdade com Antônio Nunes de Almeida. ${ }^{48}$ De acordo com Júnia Caldeira, Antônio de Almeida teria tido auxílio de Paul Villon para a execução do Projeto paisagístico. ${ }^{49} \mathrm{Na}$ praça existiam ánores de grande porte, um coreto, duas pontes com guardas com imitação de troncos, pequenos lagos, uma cascata, caminhos orgânicos e uma cópia do Pico do ltacolomi de Ouro Preto, que era uma grande rocha artificial em cimento armado em meio a um lago, que se ligava a outro por uma ponte em rocaille. As rocailles estavam distribuídas em duas pequenas ithas interligadas por duas pontes rústicas (figura 9). Numa das ilhas instalou-se a cópia do Itacolomi, e na outra, duas estátuas femininas sobre um conjunto rochoso artificial (figura 11). As figuras 8 a 11 ilustram as obras em rocaille da praça da Liberdade no início do século XX.

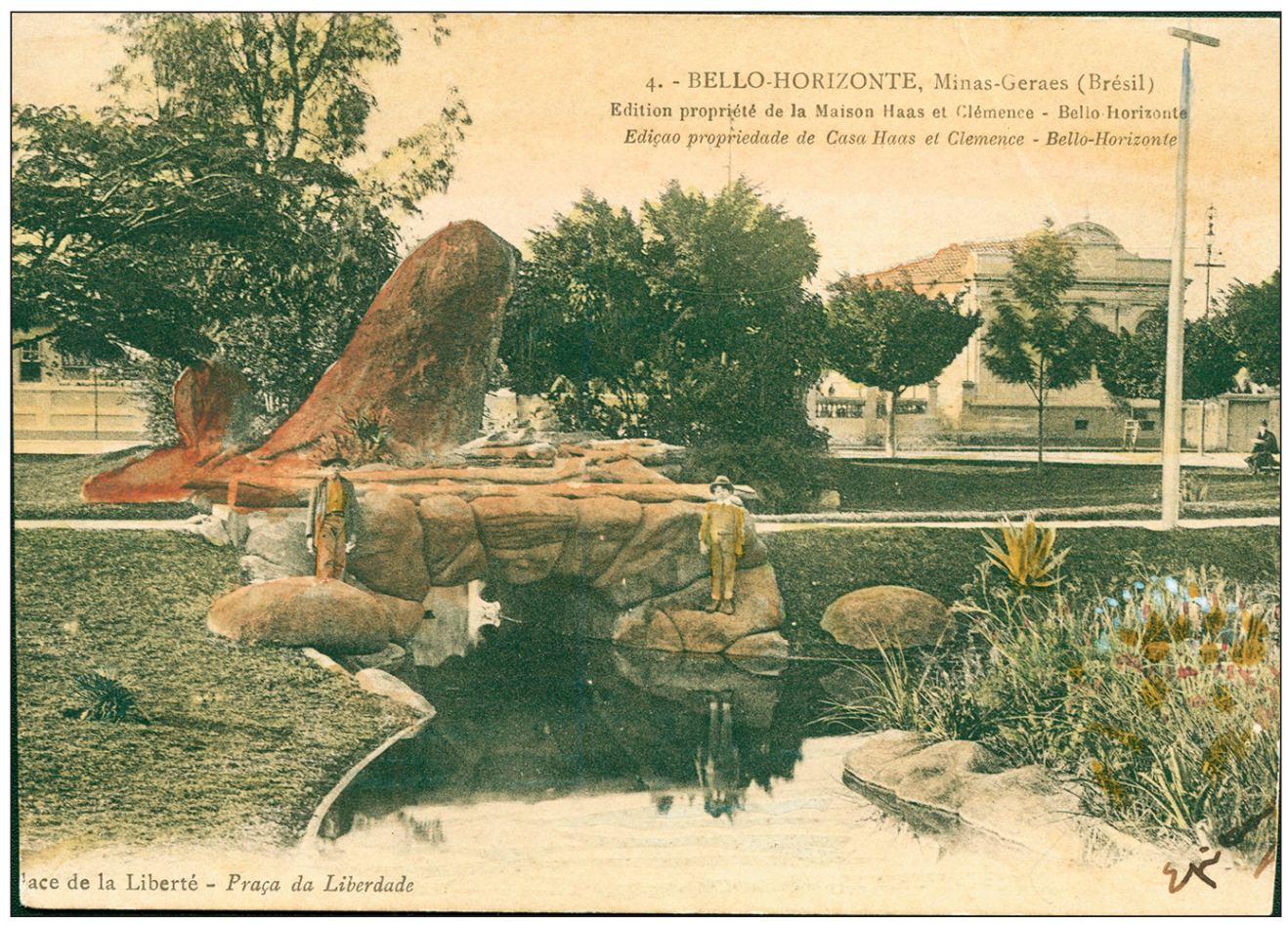

Figura 8 - Cartão-postal da praça da Liberdade, em Belo Horizonte, no início século XX, com a imitação do pico do Itacolomi. Acervo Museu Histórico Abílio Barreto (MHAB), Belo Horizonte.
46. Ver Minas Geraes (1899b).

47. Essas obras ainda podem ser visitadas no local, apesar das alterações realizadas nesse jardim.

48. Ver Francisco Bressane (1903, p. 14).

49. Ver Júnia Caldeira (2007, p. 183) 


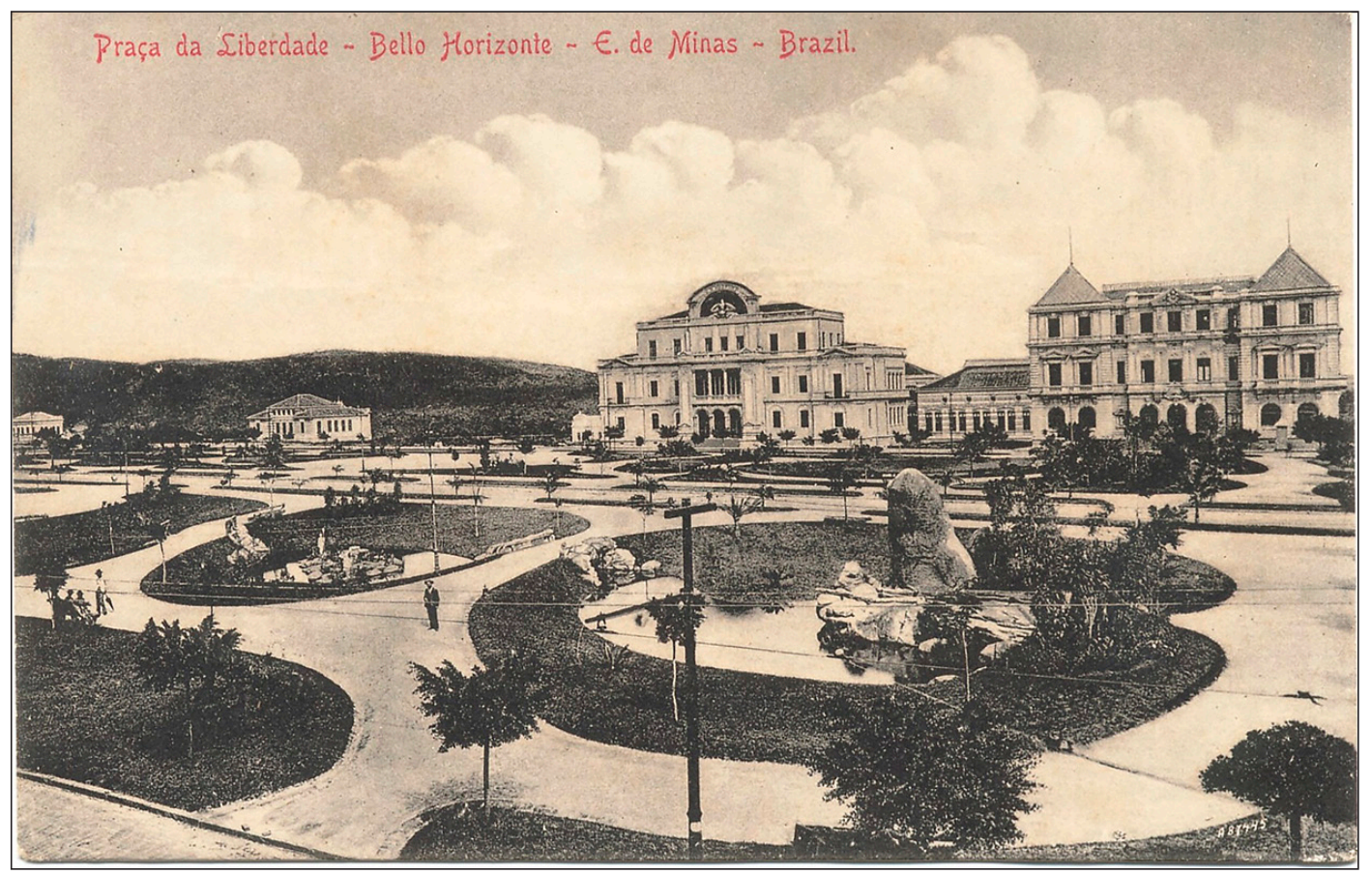

Figura 9 - Praça da Liberdade em imagem de 1910, com as rocailles em evidência em duas ilhas interligadas por ponte rústica. Acervo Museu Histórico Abílio Barreto (MHAB), Belo Horizonte.

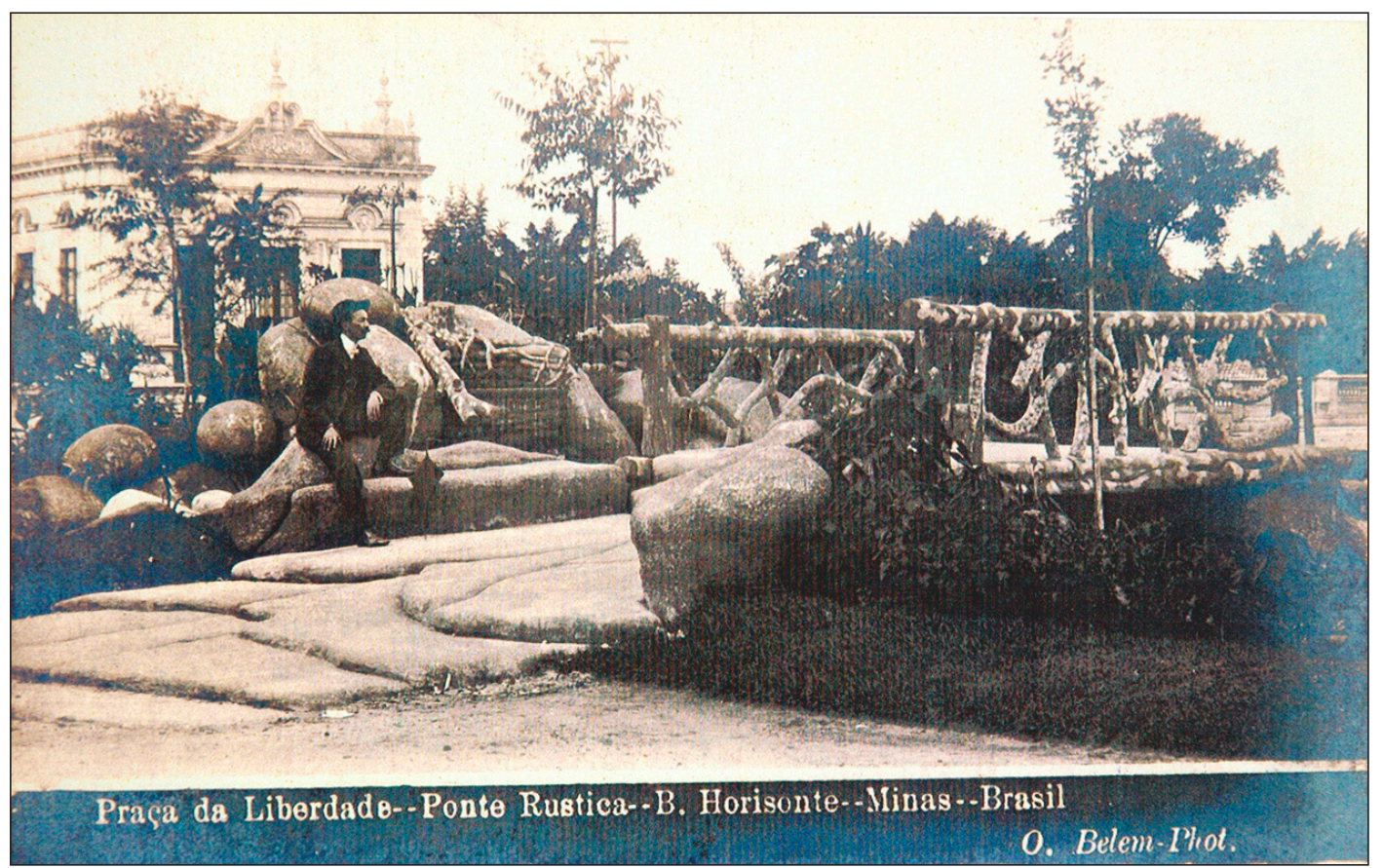

Figura 10 - Cartão-postal mostrando uma das pontes em rocaille da praça da Liberdade. Acervo Museu Histórico Abílio Barreto (MHAB), Belo Horizonte. 


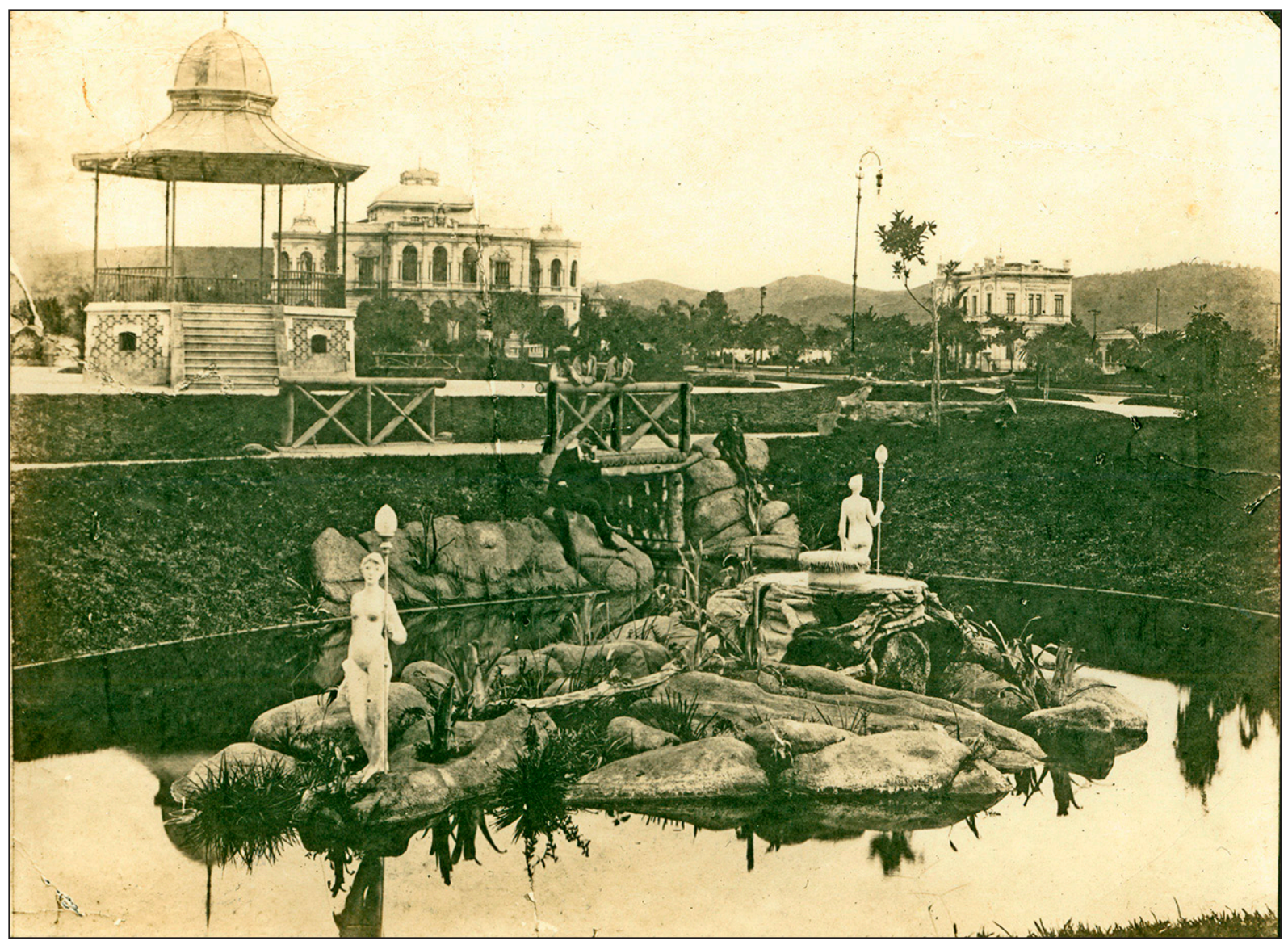

Figura 11 - Cartão-postal mostrando lago, estátuas e rocailles da praça da Liberdade. Acervo Museu Histórico Abílio Barreto (MHAB), Belo Horizonte.

Em 1899, Paul Villon exonerou-se do cargo de administrador do Parque Municipal de Belo Horizonte para assumir o de jardineiro-chefe da Inspetoria de Matas Marítimas e Terrestres de Caça e Pesca, no Rio de Janeiro. ${ }^{50}$ Essa função era exercida pelo seu cunhado, Augustin Mallemont, desde 1893, e Paul Villon a exerceu até o seu falecimento, em 1905. Nessa função, durante o governo de Pereira Passos e sob a inspeção de Júlio Furtado, remodelou e ajardinou diversas praças do Rio de Janeiro. Entre elas, destacam-se a praça XV de Novembro, o antigo largo do Rocio (atual praça Tiradentes), os jardins da Glória, o projeto para a enseada de Botafogo, os jardins da Tijuca, entre outros.

Nesses jardins do início do século XX, o conceito de paisagismo é distinto se comparado aos jardins paysagers referendados até aqui. Os jardins, praças e parques públicos perdem os seus gradeamentos, e flores são plantadas junto à 50. Ver Minas Gerais (1899a). vegetação arbórea. "No seu tempo [Glaziou], porém, estava arraigada a 
51. Cf. A Notícia (1904).

52. Cf. A Notícia (1904).

53. Cf. Correio da Manhã (1903).

54. Cf. A Notícia (1903).

55. Ver A Notícia (1903).

56. Cf. A Notícia (1903).

57. Informações e imagens desse jardim estão disponíveis em: <https:// goo.gl/RHnzc2>. Acesso em: 7 jul. 2017

58. Conforme Certidão de Óbito de Paul Villon. Acervo de Victor Villon.

59. Ver L'Étoile du Sud (1905, p. 2). convicção de que no Rio de Janeiro os jardins só deviam ter árvores e gramados e ficar fechados a sete chaves." ${ }^{11}$ Sob a direção de Julio Furtado e dos trabalhos de Paul Villon, os jardins cariocas receberam nova feição. A retirada das grades ao redor dos jardins públicos foi ressaltada em diversos artigos que trataram desses embelezamentos. Além dessas questões pontuais, principia-se a prezar pelos espaços arejados e abertos, em vez dos bosques de árvores frondosas. A ornamentação dos canteiros do jardim do Rossio, por exemplo, remodelado por Villon em 1904, obedeceu ao "sistema de mosaico usado modernamente nos jardins públicos da França, Alemanha e Inglaterra". ${ }^{52} \mathrm{~A}$ marca de Paul Villon, com execução de obras em rocaille para seus jardins, aparece no jardim da Boa Vista, no Alto da Tijuca. Ali foi construído um "pavilhão rústico sobre um rochedo, tendo em volta um gramado de flores". ${ }^{53}$

Nos jardins da Glória, Paul Villon seguiria o estilo misto ou "composito moderno, uma reprodução do criado pelo grande Le Notre". ${ }^{54}$ Sobre esse jardim, - jornal A Notícia fez uma longa reportagem anunciando que haveria platibandas de flores em numerosos desenhos art nouveau cortando os gramados. Uma parte do jardim campestre seria composto de rochedos, ruínas e troncos artificiais, com três lagos. ${ }^{55}$ "O jardim será orlado de uma calçada de cimento em mosaicos do estilo fougère e a linha externa dos gramados terá uma fila de oitis". 56 No mesmo estilo, o arquiteto paisagista Luis Rei, ao substituir Paul Villon em seu cargo, concebeu todo o jardim do Valongo com elementos decorativos em rocaille, em 1906.57 Mais uma vez, Paris seria o parâmetro para a capital da República naqueles anos de Pereira Passos, sob novos conceitos e modelos distintos dos squares do século XIX.

Com a saúde abalada, em 1905 Paul Villon viajou à França, de licença médica, para se restabelecer. Todavia, faleceu quatro meses depois, em Nice, na manhã de 9 de outubro de 1905.58 Quando da sua partida para a França, o jornal carioca L'Étoile du Sud publicou nota pontuando os trabalhos de Paul Villon no Brasil, 59 muitos deles sob a direção de Glaziou, indicando como de rocailleur ele se transformara em um paisagista. Sua longa carreira profissional e consagração como paisagista indicam que o exercício técnico de rocailleur, a partir do Campo de Santana, gerou tanto impacto que permitiu a Villon progredir radicalmente em sua carreira, levando mesmo a uma migração de status de técnico para a de um artista da paisagem, como fora Glaziou. Sua atuação em pelo menos três estados - Rio de Janeiro, São Paulo e Minas Gerais - auxiliou na difusão tanto do gosto pela imitação da natureza em cimento quanto possivelmente de suas técnicas.

A presença de cascateiros, denominação popular pela qual os rocailleurs eram chamados no Brasil, em diversas cidades, indica que o alcance das obras 
de Villon realmente se generalizou, abrindo um campo profissional para a ação de muitos outros técnicos dos quais ainda pouco se sabe. A profissionalização e a especialidade de Villon careciam de reconhecimento e chancela oficial, motivo pelo qual reconstituir suas trajetórias é sobretudo lançar mão de uma documentação dispersa pelos jornais ou pelos próprios vestígios materiais de sua atividade. Nesse sentido, reconstituir o itinerário profissional do cascateiro português Francisco da Silva Reis é, de igual modo, exemplar.

\section{FRANCISCO DA SILVA REIS E A AÇÃO DOS CASCATEIROS}

A inauguração do Campo de Santana deve ter concorrido para surgir, nos reclames dos periódicos do Rio de Janeiro, o termo cascateiro, uma forma aportuguesada para rocailleur. Encontramos no Jornal do Commercio edição de 20 de janeiro de 1879, a primeira referência quanto à designação de cascateiro para aquele que construía cascatas e rochedos artificiais em jardins. Naquela edição, anunciava-se que "o cascateiro Sávedra Martins encarrega-se de fazer cascatas e jardins, por preços módicos, e o seu trabalho afiançado. Pode ser procurado à rua da Constituição, n. 52, loja". ${ }^{60}$

Anterior a esse período, entretanto, a partir da década de 1850, encontramos diversos anúncios de "construtores de cascatas para jardins" e, também, anúncios de vendas de conchas para cascatas de jardins. $\bigcirc$ Correio Mercantil de 6 de janeiro de 1859 anunciava que o estabelecimento de mármore dos Irmãos Delpino e Ennes vendia "vasos para jardins, figuras para ditos e ricos repuchos, monumentos, túmulos, azulejos, cimento, capachos, conchas para enfeites de cascatas, etc (...) e faz-se cascatas em jardins com o mais apurado gosto". Além desses, muitos outros apareciam nos periódicos do Rio de Janeiro oferecendo serviços de construtores de cascatas para jardins. Nenhum desses anúncios anteriores ao final da década de 1870 utilizava o termo cascateiro para designar os profissionais que modelavam em cimento obras falseando o natural.

Entre 1879 e o final da década de 1920, há uma profusão de anúncios de profissionais autodenominados cascateiros nos periódicos cariocas. Alguns diziam, inclusive, possuir carta do ofício. "JARDINEIRO. Aluga-se um de primeira ordem e cascateiro e tem carta do oficio. Na rua do General Camara, 125".61 No tołal, localizamos 42 anúncios de profissionais distintos, entre 1854 e 1922, para "cascateiros" e "construtores de cascatas para jardins".
60. CF. Jornal do Commercio (1879).

61. Cf. Jornal do Commercio (1882). 
62. Cf. ALMANACH de São Paulo (1899, p. 55).

63. Cf. A Folha Nova (1921).
Analisando o conjunto documental constante dos periódicos integrantes do acervo digital da Biblioteca Nacional, nota-se que as funções de jardineiro, cascateiro, pedreiro, estucador, mestre de obras, horticultor e até pintor se confundiam. O mesmo profissional que anunciava trabalhos como "cascateiro" poderia anunciar junto a esta algumas das funções elencadas anteriormente. Lembra-se que o oficial pedreiro, originalmente, era aquele que: "faz obras de pedra, pedreiro de alvenaria, pedreiro de cantaria; canteiro", segundo os dicionários de Raphael Bluteau (1728) e de Antônio de Moraes Silva (1789). Note-se que as profissões com formações acadêmicas, como arquitetos e engenheiros, não estavam ligadas ao ofício de cascateiro.

Na década de 1890, a Inspetoria de Jardins do Rio de Janeiro pagava dois pedreiros rochistas. Nas duas primeiras décadas do século XX, a função foi substituída pela classificação de "cascateiro" da mesma Inspetoria de Matas, Jardins, Caça e Pesca, posterior Diretoria-Geral de Arborização e Jardins. O Decreto n. 1.364, de 22 de julho de 1919, que reorganizou a Inspetoria de Matas, Jardins, etc., menciona na listagem das funções do "pessoal terrestre" um cascateiro. Em 1932, o cargo de cascateiro foi substituído pela denominação "Encarregado geral de serviço", que reuniu também os "encarregados de cultura", desaparecendo completamente a referência a cascateiros nessa diretoria a partir da década de 1930.

Além da cidade do Rio de Janeiro, encontramos anúncios de cascateiros em jornais do Recife (PE), de Juiz de Fora (MG) e do sul mineiro, em cidades do circuito de águas termais e dos parques de vilegiatura. Em São Paulo, o italiano Serafim Corso anunciava seus serviços de mestre de obras, para "embelezamento de jardins, grutas, cascatas, etc.", ${ }^{2}$ sem utilizar o termo cascateiro.

A região sul do estado de Minas Gerais fornece dados que permitem reconstituir a trajetória profissional de um técnico cascateiro de imenso sucesso na decoração de jardins de cidades interioranas, especialmente aquelas ligadas à vilegiatura, em que o gosto pitoresco das rocailles ganhou grande difusão. A edição de 3 de julho de 1921 do jornal A Folha Nova, de Carmo de Minas, noticiou as obras que o português Francisco da Silva Reis empreendia na transformação da praça principal da cidade:

Bancos para o nosso jardim. O hábil cascateiro Sr. Francisco dos Reis está fazendo em os cantos e centro de nosso jardim público uns bancos de cimento armado, bancos de uma originalidade digna de nota. $\bigcirc$ primeiro que o distinto artista fez, ao lado da rua Te. Antonio, foi oferta sua ao jardim, como uma recordação dos tempos que ali trabalhou. É um tronco de árvore, cahido, tendo a base carcomida, servindo de vaso, ao lado do assento e do confortável encosto. Essa dádiva despertou a curiosidade publica e os progressistas de nossa vila animaram-se. ${ }^{63}$ 
Na cidade de Carmo de Minas, o cascateiro executou obras em rocaille para toda a praça recém-construída em 1921, tais como um repuxo, um coreto com uma cascata artificial que saía de sua parte inferior, um poste, semelhante a um tronco de árvore, e 13 bancos: três imitando troncos caídos e dez com encostos com fingimentos de bambus envoltos em cipós retorcidos. Dessas obras originais, apenas o coreto restou, com sua cobertura modificada, pois os outros equipamentos foram demolidos. ${ }^{64}$

Francisco da Silva Reis, vulgarmente conhecido como Chico Cascateiro, 65 é sem dúvida a personalidade de maior destaque no âmbito dos cascateiros que atuaram no interior do Brasil. $\bigcirc$ seu trabalho, ao que tudo indica, ficou restrito ao sul mineiro. Foram localizadas obras do artífice nas cidades de Caxambu, Baependi, Carmo de Minas, Passa Quatro, Cristina, Maria da Fé e numa fazenda em Itajubá, em praças, jardins públicos, residências urbanas e em fazendas, ${ }^{66}$ sempre com as mesmas técnicas de falseamento da natureza em cimento armado.

Além da menção ao artífice no jornal A Folha Nova, de Carmo de Minas, em Caxambu, Guilherme Nogueira de Andrade, redator-proprietário do Jornal de Caxambu, também registrou os trabalhos que o cascateiro realizava na cidade:

Não é demais avançar que, sob o envolucro de um simples operario, se occulta um extraordinario e perfeito artista. Os trabalhos rústicos do sr. Francisco da Silva Reis realizados nesta cidade aattestam, com prodigiosa exactidão, o que vimos de affirmar.

A orla do Jardim Municipal, em cimento armado, emitando, como ao natural, a madeira tosca; os pontilhões sobre o Bengo, ligando os lados do gracioso e poetico jardim; os bancos gothicos, aqui e alli, pela sombra do arvoredo; o grande bloco ou rocha como centro do pequeno lago e que serve de base a fonte luminosa, formando, em torno, linda cascata; a cascatinha do lindo coreto do jardim, etc; tudo está em relevo, como se fôra obra da natureza!

Os grupos de assentos toscos, emitação de madeira, em diversos pontos, a graciosa choupana como abrigo da bomba de excuamento de aguas pluviaes e, para maior realce, a elegante e soberba cascata e respectivo lago, fazendo-se em ponto culminante para o enlevo, agreste, de veranistas que, emmages todos grupos, posem para as classicas e proverbiaes photographia dos que aqui passam as temporadas em plena villegiatura. Em todos esses maravilhosos trabalhos de pura emitação da natureza e fina arte, ficará perpetuado o nome de Francisco da Silva Reis, o inimitavel e prodigioso cascateiro. ${ }^{67}$

Essa notícia, cujo título celebrava o ofício de cascateiro e o próprio artífice de maneira explícita, arrola os itens do principal conjunto subsistente de Francisco da Silva Reis, localizado no Parque das Águas e na praça da cidade.

No Parque das Águas, no entorno da estância termal, Francisco Reis produziu, entre 1913 e 1918, mobiliário constante de bancos, caramanchões, um
64. As outras obras descritas para essa praça foram reconstruídas no mesmo local das antigas, para compor um cenário artificial do que teria sido feito por Reis em 1921.

65. É importante registrar que Francisco da Silva Reis não era conhecido como "Chico Cascateiro" em vida Ele próprio assinava suas obras com o nome completo. Em respeito ao artífice, manteremos a grafia correta do seu nome.

66. Esse levantamento foi realizado por Eustáquio Gorgone de Oliveira e por Manuel Mata Machado na década de 1980, durante realização do Projeto Chico Cascateiro.

67. CF. Guilherme Nogueira de Andrade (1918). 
68. Michel Racine (2001, p. 105) nota que, nos parques termais franceses do final do século XIX, o modelo vigente dos jardins paysagers era pontuado com as rocailles. miradouro com cascata e lago, casa de máquinas, quiosque, pontes, entre outros equipamentos. Em todas as suas obras sobressai a minúcia na reprodução de detalhes da natureza, como cogumelos (as "orelhas de pau"), os fingimentos de bambus e de insetos, os retorcidos e entrelaçamentos dos cipós. Nas representações dos troncos de árvores e dos cipós, Francisco Reis inspirou-se nas espécies tropicais para reproduzir texturas rugosas, além de bambus e o cipó-cruz, proporcionando um caráter excepcional e exótico às suas obras (figura 12 a 15).

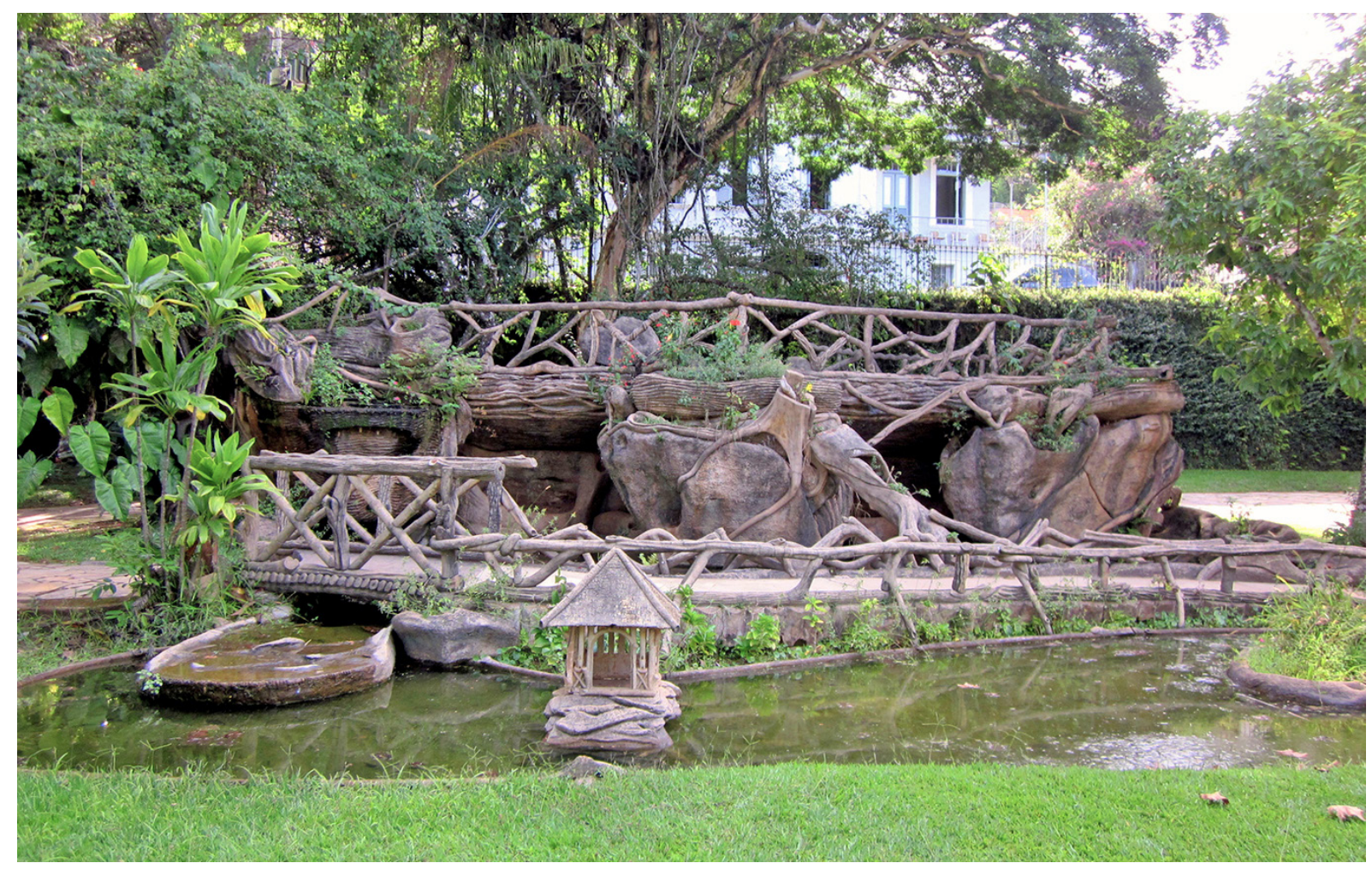

Figura 12 - A obra principal: um mirante com gruta artificial e um pequeno lago com casa para patos. Francisco da Silva Reis, Parque das Águas de Caxambu. Fotografia de Cristiane Magalhães, 2014.

Caxambu era, a esse tempo, o principal local de vilegiatura das elites do Rio de Janeiro em busca de águas curativas. $O$ trabalho de Francisco Reis dava ao parque termal de Caxambu uma aparência que o assemelhava àqueles decorados por Villon na capital brasileira de então, ${ }^{68}$ o que certamente foi fator que favoreceu a adoção do padrão pitoresco e das rocailles na cidade. Além de Caxambu, outras cidades do sul mineiro contrataram o cascateiro português, possivelmente dentro da mesma expectativa de assemelhar-se não mais a Paris, mas ao modelo carioca, mais próximo e reconhecível como padrão a ser alcançado. 


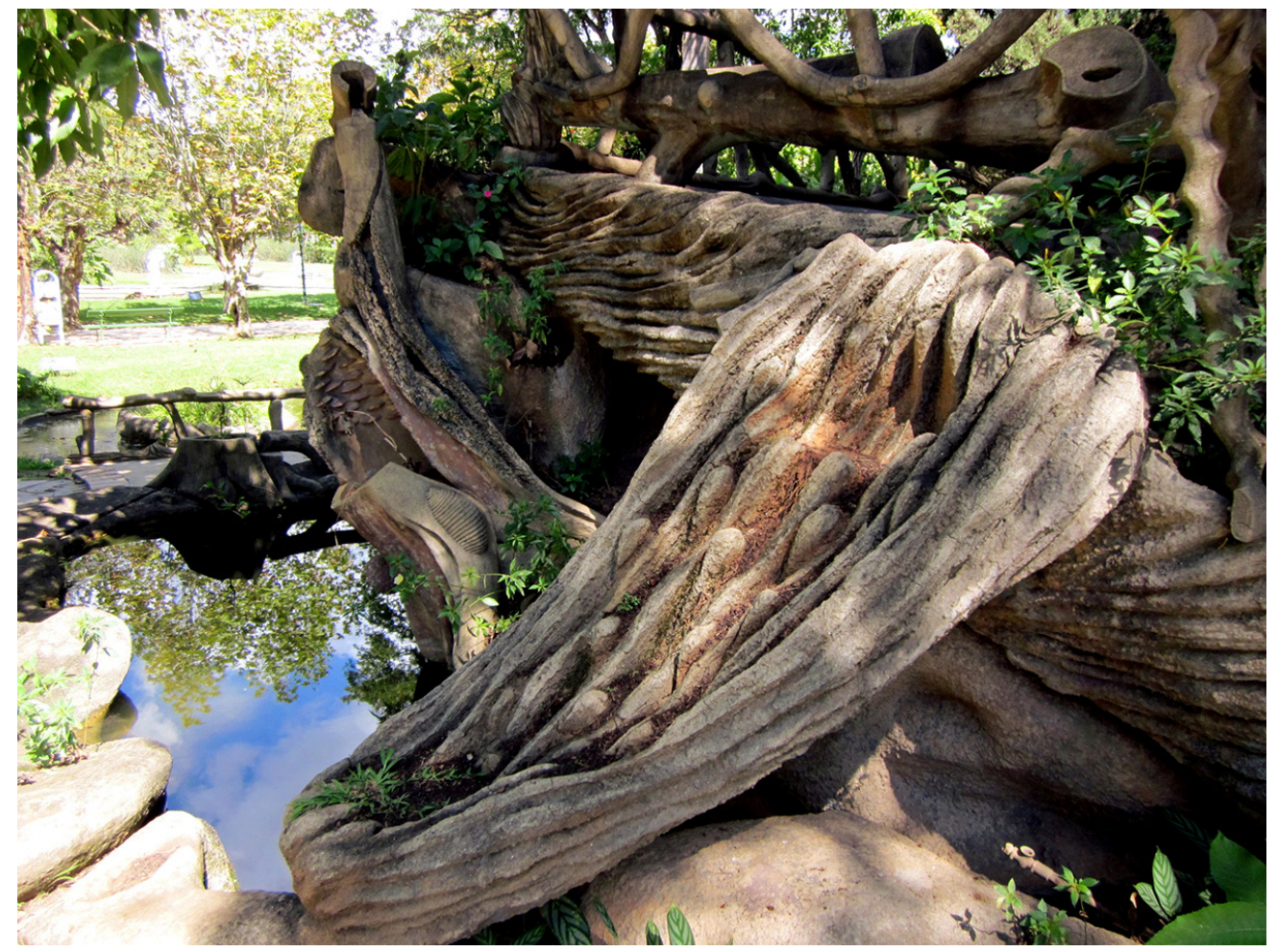

Figura 13 - Detalhe da composição escultórica de Francisco da Silva Reis no mirante de Caxambu. Fotografia de Cristiane Magalhães, 2014.

Na cidade de Cristina (MG), durante reformas no jardim da praça Santo Antônio, o cascateiro construiu um pedestal para uma escultura de Leão e uma fonte conhecida como Peixinho. 69 A data desse trabalho não é precisa. Os jardins foram construídos entre 1908 e 1909, porém há referências ao trabalho de Francisco Reis no local apenas nos anos 1920. Em Baependi, próxima a Caxambu, ele trabalhou em 1916 na praça Monsenhor Marcos, executando um chafariz com bordas em rocaille. ${ }^{70}$ Em Passa Quatro, atuou entre janeiro e agosto de 1922, construindo, na praça central, um pavilhão para a fonte de água, um grande repuxo semelhante ao de Carmo de Minas, além de bancos com imitação de troncos, na companhia do estucador português José Antônio Faustino. Em Maria da Fé, o artífice viveu no ano de 1926, realizando as obras da praça da Matriz de Nossa Senhora de Lourdes e em residências particulares. ${ }^{71}$ Ainda em 1926, executou os jardins da Fazenda do Goiabal, em Itajubá. ${ }^{72}$ A partir desse ano, desaparecem os vestígios deixados pelo cascateiro português.

repertório decorativo do artesão português se fez com utilização estrutural de alvenaria de tijolos e ferro, modelados em cimento armado e aplicação de
69. Informações e imagens sobre a fonte do Peixinho podem ser obtidas em: $<$ ht tps://goo.gl/QxEOYC>. Acesso em: 01 mar. 2017.

70. Ver Eustáquio Gorgone Oliveira (s.d., p. 28).

71. Ver Eustáquio Gorgone Oliveira (s.d., p. 28).

72. Ver Eustáquio Gorgone Oliveira (s.d., p. 33). 


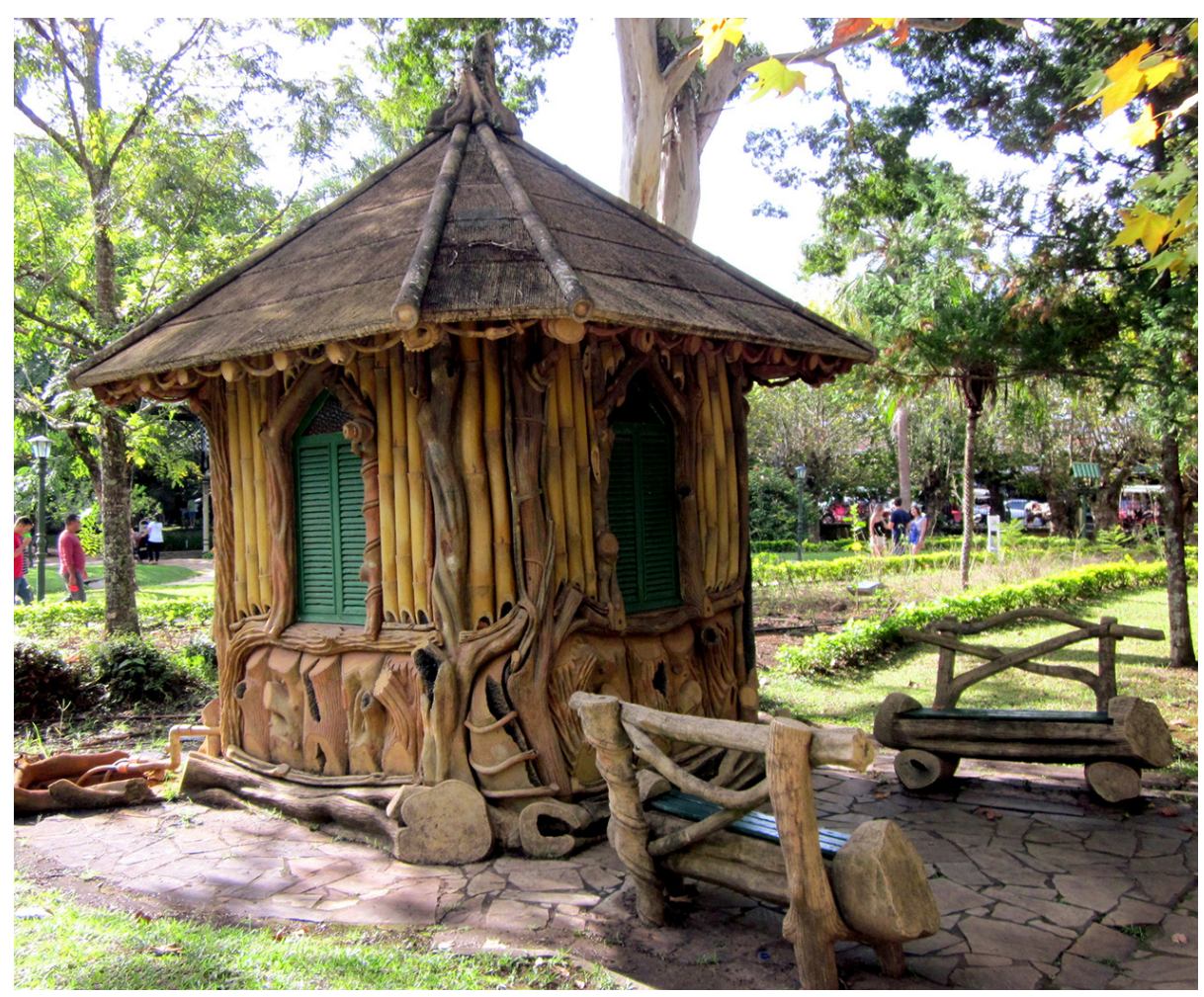

Figura 14 - Casa de máquinas e bancos modelados em cimento armado por Francisco da Sitva Reis no Parque das Águas de Caxambu. Fotografia de Cristiane Magalhães, 2014.

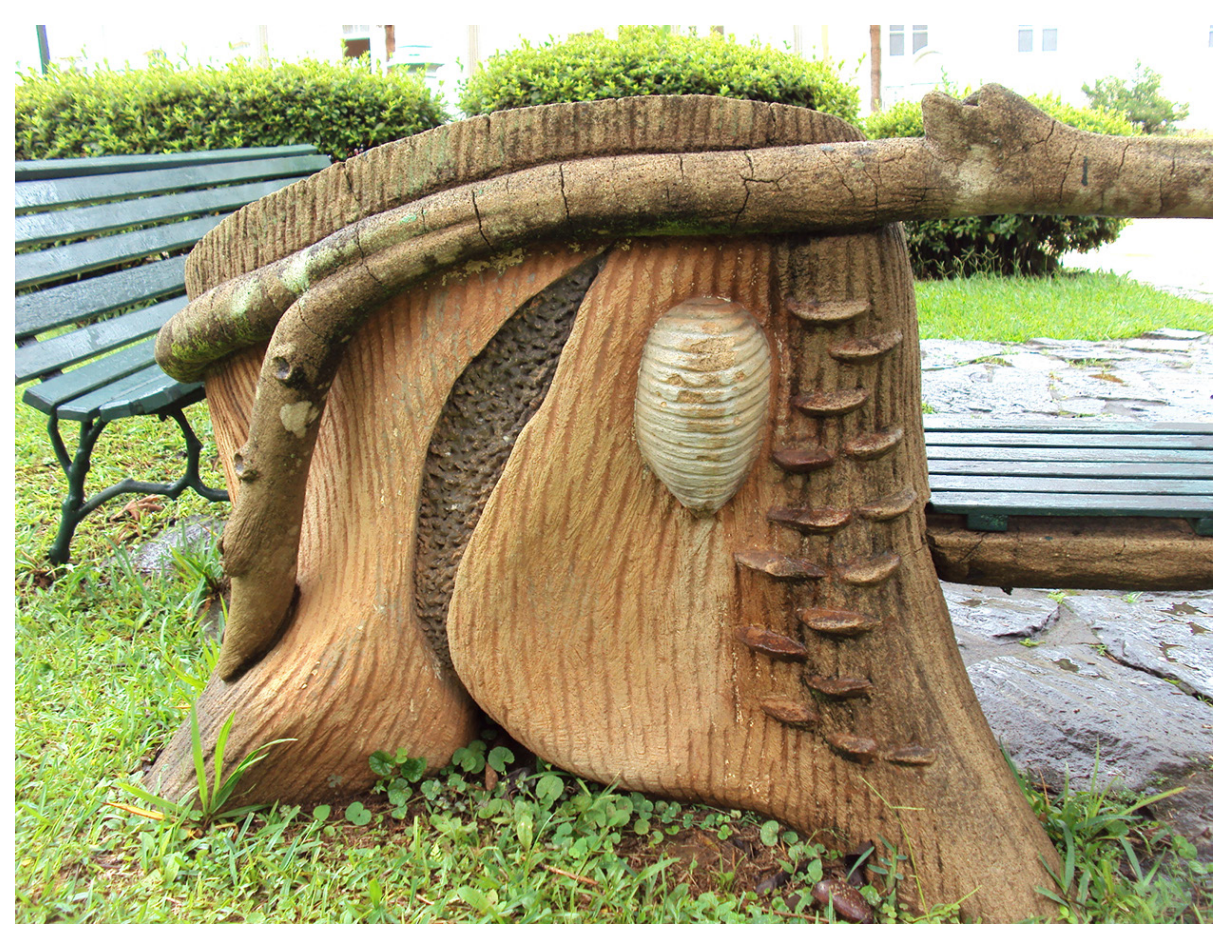

Figura 15 - Detalhe da base de um dos bancos do Parque das Águas. Francisco da Silva Reis. Fotografia de Cristiane Magalhães, 2014. 
pigmentos naturais para coloração. Em entrevistas realizadas pelo poeta e pesquisador Eustáquio Gorgone de Oliveira (1949-2012), identificou-se que a argamassa produzida pelo artesão-paisagista era composta de areia, cimento, óleo de baleia, pedaços de tijolos, manilhas, cacos de telhas coloniais e francesas, além de cerâmica para os acabamentos. $\bigcirc$ óleo de baleia servia para dar liga à massa e proporcionar impermeabilidade à água. Francisco Reis não usava tintas e, nas representações de bambus, empregava pigmentação para dar coloração natural à reprodução. Ele próprio produzia suas ferramentas de trabalho ou as adaptava, segundo relatos dos ajudantes que o auxiliavam nas cidades por onde passou. ${ }^{73}$ "Ele usava uma colher de pedreiro com bico fino, bicudinha, uma espátula e desempenadeira curta. A massa enxugava e com um arame dava o corte", segundo depoimento de Juca Artur, antigo morador de Cristina. ${ }^{74}$ A questão das ferramentas de trabalho para os artífices é fundamental. Por esse motivo, importa explicitar que Francisco Reis executava as suas próprias ferramentas.

Um traço autoral e característico de Francisco da Silva Reis e que o diferencia dos demais cascateiros que atuaram no Brasil era o de assinar as suas obras na argamassa ainda fresca, normalmente em local visível e acessível (figuras 16 e 17). Em Carmo de Minas, o coreto da praça da Matriz contém a assinatura "F.S.Reis" e, logo abaixo, a data "1921". Ao lado da sua assinatura ele desenhou, ainda, um pequeno ramo. No mirante do Parque das Águas de Caxambu, sua obra mais significativa, assinou o nome completo e datou (1918). Eustáquio Gorgone relata que encontrou outra obra assinada de Francisco Reis na Fazenda do Goiabal (ltajubá, 1926). "Trata-se de uma mesa apoiada sobre uma única coluna, onde o artista deixou gravada as iniciais F.S.REIS, contra o fundo amarelo-claro de uma argamassa que se mostra como osso na sua resistência e finge idade bem mais remota". ${ }^{75}$

Além da assinatura, o artífice desenhava símbolos discretamente dispostos nas modelagens de suas obras, ora uma rosa, ora pequenos ramos, ora insetos (Figura 18). A preocupação de Francisco Reis com a reprodução de detalhes em suas obras o fez esculpir pormenores como a alusão às raízes de árvores, como se vê na figura 19. As características autorais de assinar as obras expressam uma peculiaridade de Francisco Reis que infringia, assim, um limite tradicionalmente imposto aos artífices, marcados pelo anonimato, indicando que, a seu ver, sua ação já deixara de ser apenas a de um "feitor" ou um mero copista.

Na França, Michel Racine também identificou diversos rocailleurs que assinavam suas obras. Racine acredita que o ato de assinar as obras fazia com que os rocailleurs, sem querer renegar a cultura popular, também aspirassem à cultura da elite e reivindicavam para si um estatuto particular do artista no mundo
73. Ver Eustáquio Gorgone Oliveira (s.d., p. 25).

74. Cf. Eustáquio Gorgone Oliveira (s.d., p. 41).

75. Cf Eustáquio Gorgone Oliveira (s.d., p. 34). 
76. Ver Michel Racine (2001, p. 144). burguês, que se identifica com assinatura em suas obras. ${ }^{76}$ Assim, a adesão de Francisco Reis à prática de assinar suas obras indica, uma vez mais, sua ligação com a tradição dos rocailleurs franceses, já que em Portugal nenhuma assinatura foi identificada nas obras em rocaille e, até o momento, também não foram identificadas assinaturas em outras obras do Brasil.

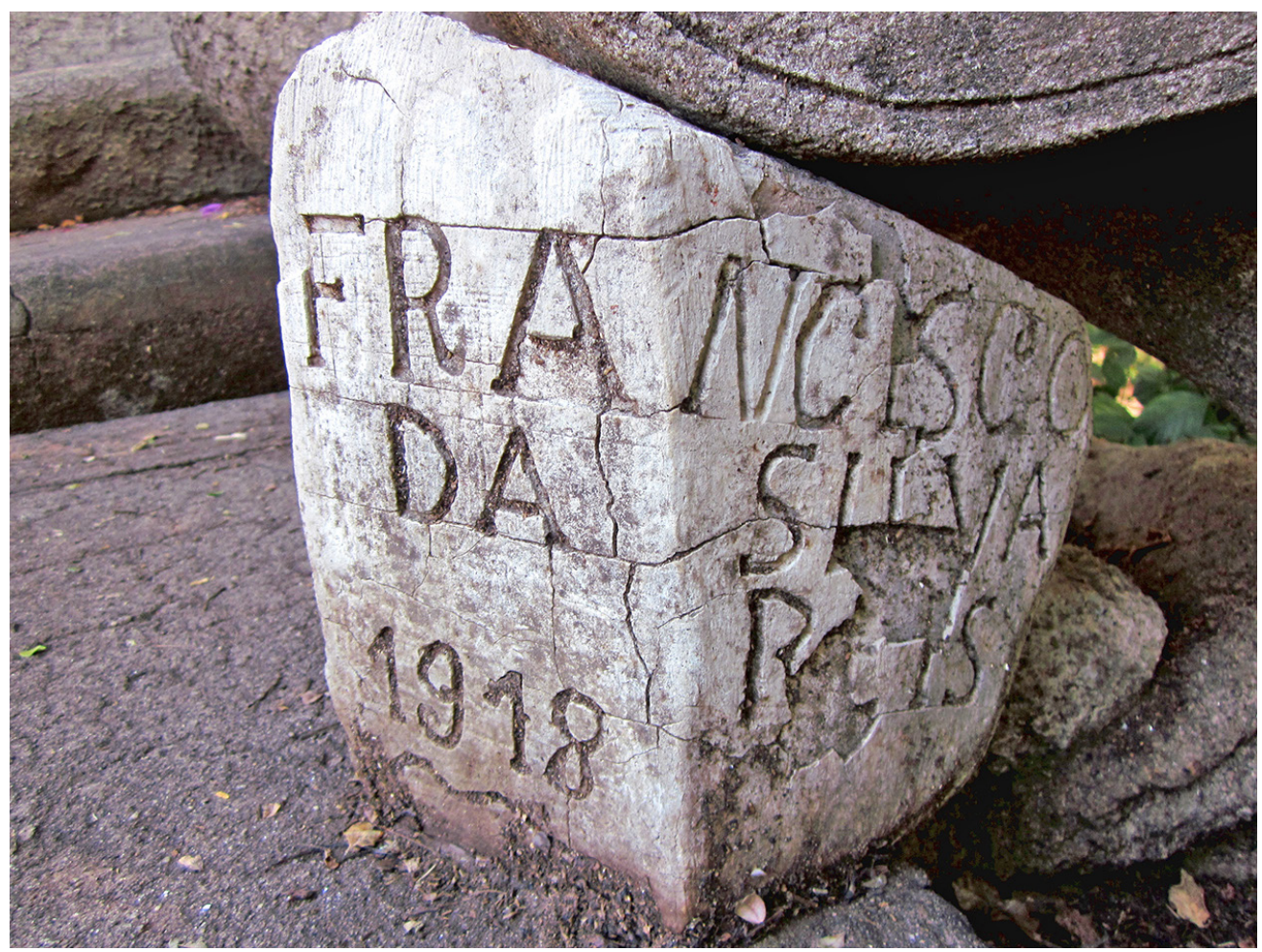

Figura 16 - Assinatura de Francisco da Silva Reis no mirante do Parque das Águas de Caxambu. Fotografia de Cristiane Magalhães, 2014.

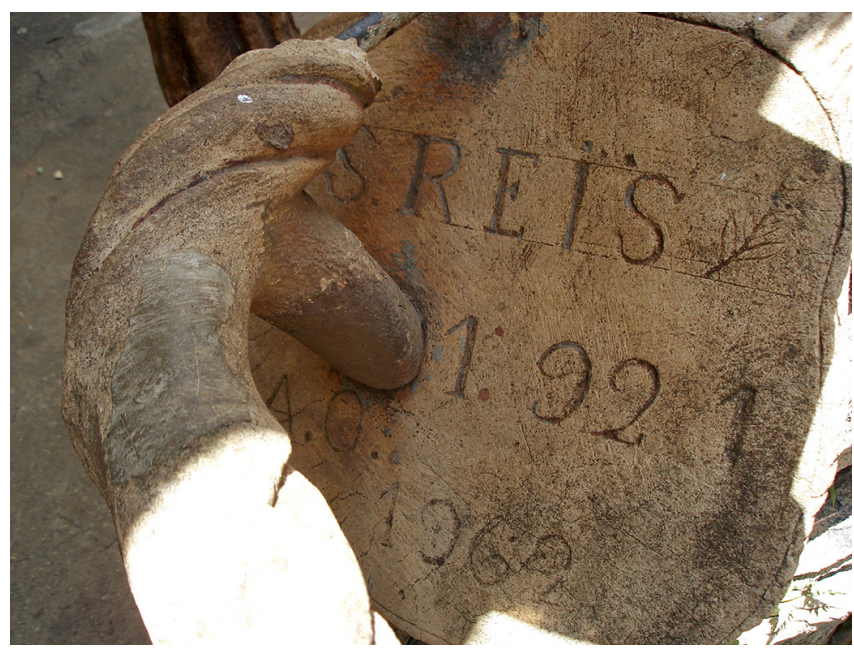

Figura 17 - Assinatura de Francisco da Silva Reis e desenho de um ramo, com a data de 1921 , no coreto da praça em Carmo de Minas. Fotografia de Cristiane Magalhães, 2006 

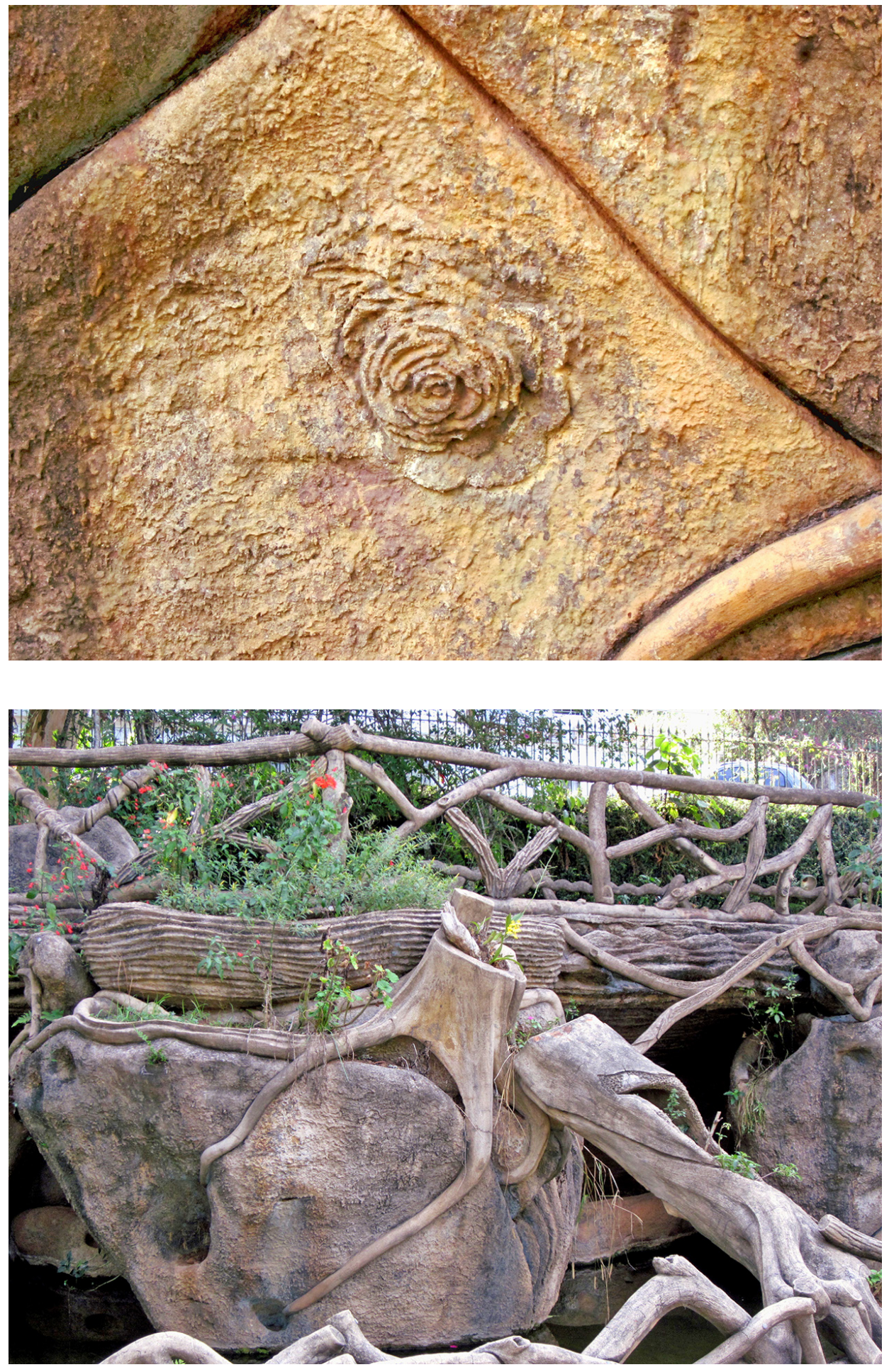

Figura 18 - Rosa entalhada na pedra artificial no Parque das Águas de Caxambu. Fotografia de Cristiane Magalhães, 2014.
Figura 19 - Detalhe do conjunto escultórico de Francisco da Silva Reis no Parque das Águas de Caxambu. Fotografia de Cristiane Magalhães, 2014. 
Restauros e reconstruções equivocadas dos últimos anos, a partir do reconhecimento do trabalho e da grande projeção do nome de Francisco da Silva Reis, têm descaracterizado e modificado a expressão singular de suas obras. Em algumas cidades do sul mineiro ocorreu, inclusive, reconstrução das obras que haviam sido destruídas ao longo do século XX, como nas cidades de Carmo de Minas e de Cristina (figuras 20 e 21 ).

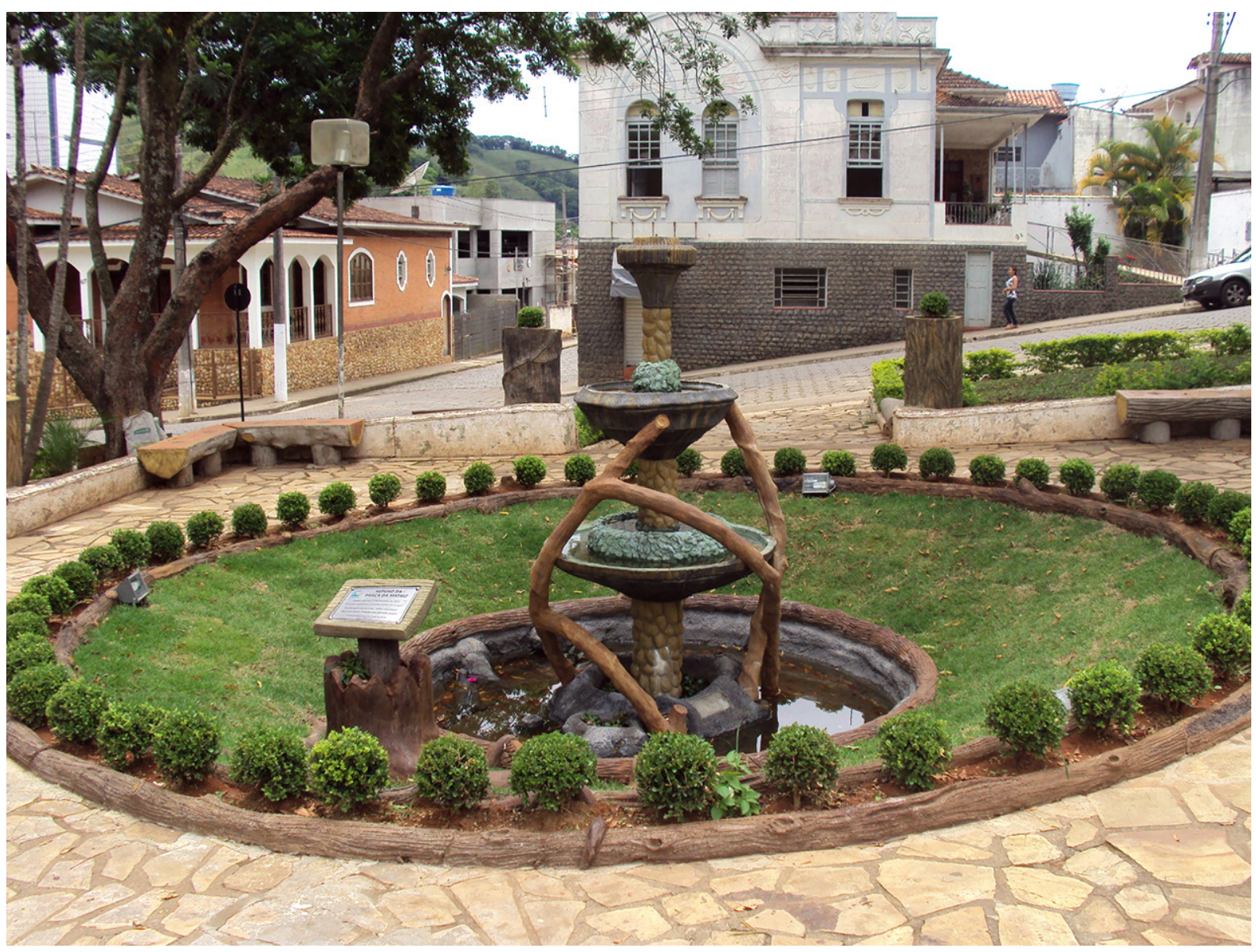

Figura 20 - Reconstrução do repuxo e de bancos imitando troncos na praça de Carmo de Minas, feita pelo artesão José Ronaldo Guerra em 2011 . Fotografia de Cristiane Magalhães, 2011.

Colocando em perspectiva, a notável diferença entre as obras em rocaille de Paul Villon ou de outros cascateiros que atuaram no Brasil, se comparadas com as de Francisco da Silva Reis, consiste na precisão plástica dos detalhes e na perfeição técnica deste último. As obras de Francisco da Silva Reis podem ser facilmente confundidas com elementos naturais, pela minúcia com que as executou, além da notável qualidade do seu trabalho. $\bigcirc$ conjunto escultórico do 


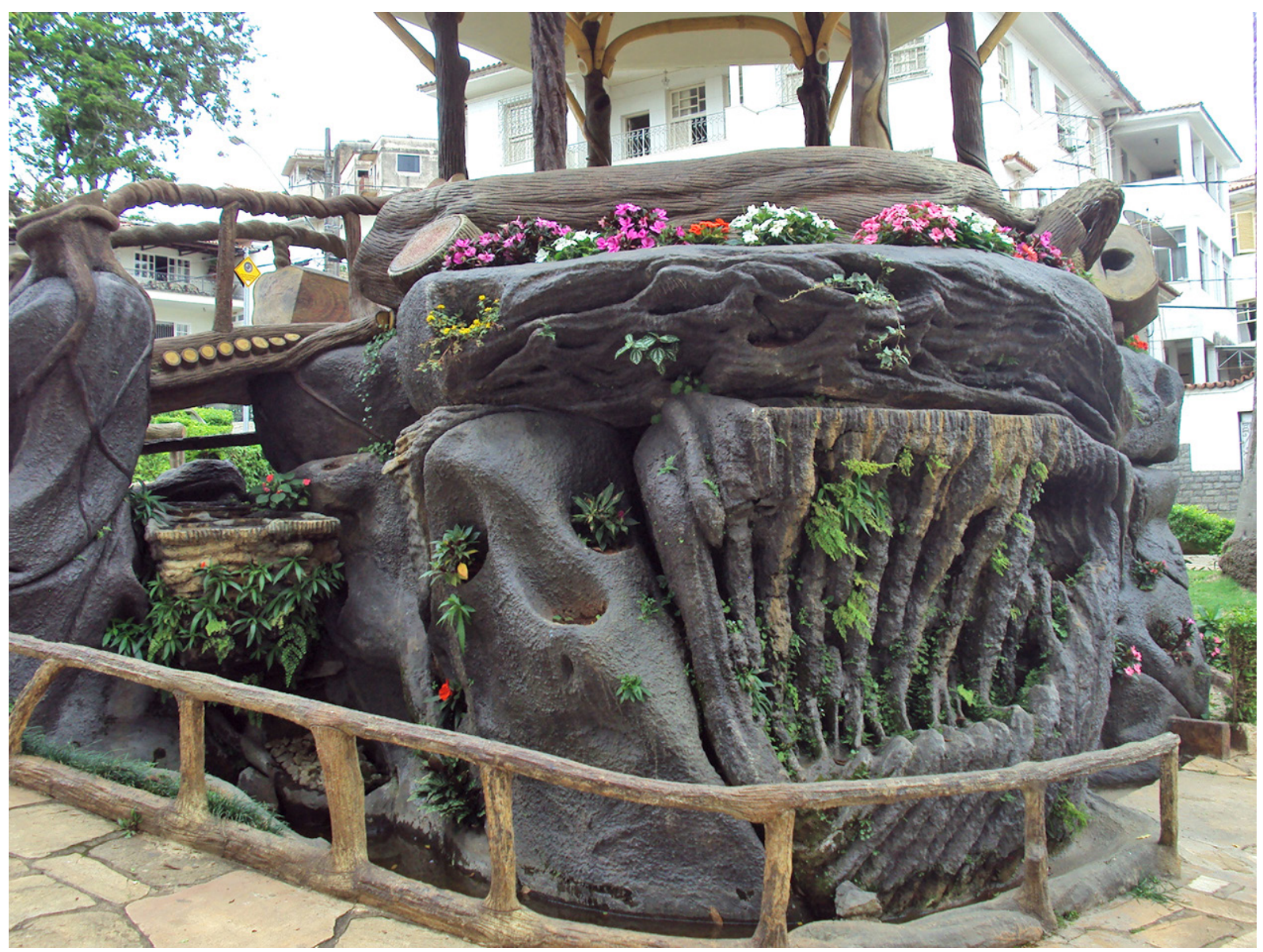

Figura 21 - Detalhe do coreto original de Francisco da Silva Reis após receber camadas de pintura, durante reconstrução das obras do cascateiro, em 2011 . Praça de Carmo de Minas. Fotografia de Cristiane Magalhães, 2011.

Parque das Águas de Caxambu, por exemplo, decorrido quase um século da execução, ainda mantém integralidade e feição semelhantes às constituídas por Francisco Reis em 1918

Se para o rocailleur Paul Villon foi possível localizar substancial documentação para recompor sua trajetória profissional e biografia, embora sem foco no seu ofício de rocailleur, para o cascateiro Francisco da Silva Reis praticamente tudo ainda é mistério. Nada se sabe de sua família, onde morava ou quando teria falecido. Nenhuma menção ao seu nome foi feita nos periódicos, cartões-postais e fotografias que usavam suas obras como pano de fundo ou nas descrições dos locais onde elas estavam após o fim dos trabalhos. ${ }^{77}$ A ascensão do paisagismo filiado ao modernismo acabou por desprestigiar os projetos 77. Ver Eustáquio Gorgone marcados pela plástica paysagère e pelas rocailles dos cascateiros, levando, Oliveira (s.d., p. 16). muitas vezes, à supressão desses ornamentos e à renovação paisagística de praças 
78. Ver Michel Racine (2001) e Teresa Marques (2009).

79. Cf. Adolpho Morales de los Rios (1911, p. 239), grifo nosso. das capitais e de cidades do interior. Outros profissionais como Francisco Reis podem mesmo ter existido, mas deles não resta qualquer notoriedade ou obras remanescentes - apagamento que foi uma constante tanto aqui no Brasil como na Argentina, na França ou em Portugal. ${ }^{78}$

\section{CONSIDERAÇÕES FINAIS}

Nas primeiras décadas do século XX, prenuncia-se o fim do jardim paysager. Num primeiro momento, isso ocorre ainda numa mescla dessa tipologia de jardim com o de linhas simétricas e planas com vistas abertas e sem cercamentos, a partir dos trabalhos de Paul Villon, no Rio de Janeiro de Pereira Passos, e de paisagistas como Arséne Puttemans e Reinaldo Dierberger. Os valores pitorescos vão perdendo sentido nos jardins e parques a partir da década de 1920 e, junto a essa mudança de concepção, o signo mais proeminente do pitoresco, as rocailles, gradativamente é apagado. Esse movimento ganha força nos anos 1930-1940 e, dali em diante, se intensifica com os planos urbanísticos de Alfred Agache e os jardins predominantemente modernistas de Mina Klabin Warchavchik e de Roberto Burle Marx.

A partir da década de 1930, arquitetos defendem o fim do reinado dos cascateiros e, com essa finalidade, decretam igualmente o desaparecimento das rocailles no paisagismo. Uma dessas menções foi feita pelo célebre arquiteto Adolfo Morales de los Rios (1 858-1928), autor de incontáveis projetos na cidade do Rio de Janeiro, no texto "Mestres, Architectos e Senhorios", publicado por $\bigcirc$ Brazil Artistico no ano de 1911 . Nesse artigo, Los Rios realiza uma descrição a respeito da história da construção e da arquitetura no Brasil enfatizando a função dos cascateiros:

Depois disto apareceu o reinado do cascateiro, que tudo fazia a cimento e em rústico, convertendo os passados chalets-suissos em construções de florestas, imitando todas as partes da obra troncos d'árvore. Foi a época em que triunfaram a cascata, com o seu inevitável e minúsculo moinho de vento a mover constantemente as suas pás, bem como o repuxo, a ponte rústica, os telhados imitando sapés, os kioskes de jardim de cobertura afunilada, as varandas de troncos d'árvore a cimento, e até... cães de guarda feitos de cimento, nos vãos de algumas casas, como ainda se pode ver num prédio à Rua da Passagem. Às vezes o rústico a cimento, o suisso a recorte de madeira, a cerâmica do Porto e as decorações de estuque de pressuposto gosto clássico se misturavam na mesma obra. ${ }^{79}$

No mesmo sentido, José Marianno Filho, em artigo para $O$ Malho de 1919, intitulado "O abandono dos nossos jardins", também cita os "cascateiros 
empavonados" sobre os quais deveria vencer a reação da cultura estética e do bom gosto. ${ }^{80}$ Paradoxalmente, esses artigos atestam o reconhecimento dos cascateiros e de sua importância para um período da história da arquitetura e da arte dos jardins no Brasil, ao mesmo tempo em que sinalizam o fim de uma era: a dos jardins paisagistas com caminhos orgânicos e ornados fartamente com as rocailles. Era necessário um novo modelo, desenhado por mãos de arquitetos diplomados, inspirados por novas e distintas concepções arquitetônicas e paisagísticas, a partir de criações estéticas academicistas da arquitetura e da arte. A escolha, como se sabe, foi pelas linhas modernistas que alçariam o Brasil aos compêndios da história do paisagismo do século XX, com o renomado Roberto Burle Marx.

Os jardins com elementos pitorescos inspirados nos squares e parques franceses do século XIX começam a desaparecer das praças, dos jardins públicos e das residências. Ornatos como grutas, pontes, caramanchões, bancos e cascatas em rocaille vão sendo gradativamente demolidos e substituídos por outros estilos então mais modernos, como foi o caso da Praça da Liberdade, em Belo Horizonte. Inclusive, o vocábulo cascateiro, nos periódicos das décadas de 1930 e 1940 e a partir de então, passa a se associar àquela pessoa que conta mentira, os trambiqueiros, os que enganam a fé pública. Nos dicionários atuais, como o Hovaiss, cascateiro possui apenas a acepção relacionada a quem conta mentiras ou engana. Nem mesmo na etimologia da palavra restou alguma referência que associe cascateiro ao antigo ofício de construtores de rocailles ou jardineiros. vocábulo rocailleur, porém, teve destino mais feliz e se mantém designando os construtores de cascatas, grutas e elementos pitorescos para jardins, em cimento ou concreto armado.

Os casos estudados neste artigo para os ofícios ligados aos jardins e parques, em especial o de rocailleur e cascateiro, centrados nas figuras de Paul Villon e de Francisco da Silva Reis, sinalizam uma prática comum sobre a qual ainda se conhece pouco no Brasil. O processo de imigração de grandes contingentes de trabalhadores, principalmente europeus, foi fator essencial para a constituição do modelo paisagístico romântico e suas técnicas correlatas aqui no Brasil.

A especialização desses homens, muitos deles educados nos Liceus de Artes e Ofícios dos países europeus, habilitou uma enorme quantidade de imigrantes a atuar no Brasil em demandas cuja mão de obra era até então inexistente aqui. No entanto, como observa Racine, a especialização dos rocailleurs franceses, ofício do qual descendem tanto Paul Villon quanto Francisco da Silva Reis, mesmo que de forma indireta para o caso do segundo, se dava, na maioria das vezes, nos próprios canteiros de obras por meio da observação e da execução prática. Para 
81. Ver Michel Racine (2001).
Racine, os rocailleurs eram, em sua maioria, autodidatas que descendiam de uma tradição familiar de horticultores, pedreiros ou de outros ofícios correlatos à construção, ${ }^{81}$ como nos mostrou exemplarmente o caso de Paul Villon.

O exame dos vestígios dessas obras, sejam documentais, sejam dos ornamentos remanescentes, indica que as rocailles não apenas foram bastante presentes no Brasil como puderam ser aplicadas e adaptadas à natureza local, dentro de certa liberdade artística popular própria desse ofício. Se o princípio imitativo era central no trabalho dos rocailleurs, o olhar para a flora e a fauna tropicais, tão explícito no trabalho de Francisco da Silva Reis, indica que, ao serem agentes de uma transferência paisagística entre a Europa e América, reinventaram seu repertório e também os limites criativos de sua profissão. 


\section{REFERÊNCIAS}

FONTES

ALMANACH da Provincia de São Paulo: Administrativo, Commercial e Industrial. São Paulo, Jorge Seckler, 1899.

ALMANAK ADMINISTRATIVO, MERCANTIL E INDUSTRIAL DO RIO DE JANEIRO. Rio de Janeiro: Eduardo e Henrique Laemmert, 1894-1899. Anual.

ALPHAND, Adolphe. Les Promenades de Paris: Histoire, Description des Embellissements, Depenses de Creation et d'Entretien des Bois de Boulogne et de Vincennes, Champs-Elysees, Parcs, Squares, Boulevards, Places Plantees. Paris: J. Rothschild Editeur, 1867-1873. 2 v.

ANDRADE, Guilherme Nogueira de. Francisco da Silva Reis - O cascateiro. Jornal de Caxambu, Caxambu (MG), n. 89, 15 set. 1918.

ANDRÉ, Édouard. L'art des jardins: traité général de la composition des parcs et jardins. Paris: [s.n.], 1879.

O APÓSTOLO, Rio de Janeiro, 29 jun. 1879.

BRESSANE, Francisco. Relatório apresentado ao Conselbo Deliberativo pelo prefeito Francisco Bressane de Azevedo. Belo Horizonte, 10 de setembro de 1903. Relatório.

CHEVREL, M. Bulletin de la Société D'Horticulture de Cherbourg. Paris: [s.n.], 1846.

O COMMERCIO de São Paulo, São Paulo, 11 ago. 1907.

COMISSÃO CONSTRUTORA DA NOVA CAPITAL DE MINAS GERAIS. Acervo digital. Disponível em: <http://comissaoconstrutora.pbh.gov.br>. Acesso em: 01 nov. 2016.

Revista Geral dos Trabalbos. Belo Horizonte: H. Lombaerts \& C, 1895.

CORREIO da Manhã, Rio de Janeiro, 13 out. 1903. 
D. July. Chronicas fluminenses. Revista Illustrada, Rio de Janeiro, ano 5, n. 222, p. 2, 4 set. 1880.

DEPOIMENTO do Justificante. Rio de Janeiro, 1 fev. 1884. Arquivo da Cúria do Rio de Janeiro.

DIÁRIO de Notícias, Rio de Janeiro, 13 fev. 1895.

L'ÉTOILE du Sud, [S.1.], 11 jun. 1905.

A FOLHA Nova, Carmo de Minas, 3 jul. 1921.

JARDIM do Campo da Acclamação. Revista Illustrada, Rio de Janeiro, n. 223, p. 4-5, 1880.

JORNAL da Tarde, São Paulo, 1 dez. 1879.

JORNAL de Caxambu, Caxambu, edição n. 89, 15 de setembro de 1918.

JORNAL do Commercio, São Paulo, 22 maio 1897.

JORNAL do Commercio, Rio de Janeiro, 25 de janeiro de 1874.

Rio de Janeiro, 20 de janeiro de 1879.

Rio de Janeiro, 22 de março de 1882.

LAEMMERT, Eduardo; LAEMMERT, Henrique. Almanak Administrativo, Mercantil e Industrial do Rio de Janeiro. Rio de Janeiro: Typ. Universal de Laemmert, 1862.

; __ Almanak Administrativo, Mercantil e Industrial do Rio de Janeiro. Rio de Janeiro: Typ. Universal de Laemmert, 1864.

O JARDIM do Rossio. A Notícia, Rio de Janeiro, 13 ago. 1904.

MARIANNO FILHO, José. O abandono dos nossos jardins. O Malbo, Rio de Janeiro, n. 875, p. 32, 21 jun. 1919.

MARSY, François-Marie de. Dictionaire abregé de peinture et d'architecture. Paris: [s.n.], 1746. Tome second. Disponível em: <https://goo.gl/aB1QVF>. Acesso em: 01 nov. 2016. 
MEPHISTOPHELES, Rio de Janeiro, ano 2, n. 55, 1874. Acervo digital da Biblioteca Nacional. Disponível em: <https://goo.gl/25wafG>. Acesso em 01 de novembro de 2016.

MINAS Geraes, Ouro Preto, 25 out. 1894a.

Ouro Preto, 23 nov. 1894b.

Ouro Preto, 23 out. 1897.

Ouro Preto, 30 maio 1899a.

Ouro Preto, 9 jul. 1899b.

MORALES DE LOS RIOS, Adolpho. Mestres, Archetectos e Senhorios. In: SOCIEDADE PROPAGADORA DAS BELAS ARTES E DO LICEU DE ARTES E OFÍCIOS DO RIO DE JANEIRO. O Brazil Artistico - Nova Phase. Rio de Janeiro: Typographia Leuzinger, 1911.

A NOTÍ́CIA, Rio de Janeiro, 22 ago. 1903.

O PHAROL, Juiz de Fora, 14 set. 1891.

RODRIGUES, Francisco de Assis. Diccionario technico e historico de pintura, esculptura, architectura e gravura. Lisboa: Imprensa Nacional, 1875. Disponível em: <https://goo.gl/ qMQM0z>. Acesso em: 01 nov. 2016.

SAGERET, Eugène. Annuaire du bâtiment, des travaux publics et des arts industriels. Paris: au bureau de l'Annuaire du bâtiment, 1903.

LIVROS, ARTIGOS E TESES

ANDRADE, Inês El-Jaick. A preservação da ornamentação rústica em jardins históricos: técnica da argamassa hidráulica de cal aditivada com cimento em rocaille. In: ANDRADE, Rubens de; PESSOA, Ana; FASOLATO, Douglas. Jardins históricos: a cultura, as práticas e os instrumentos de salvaguarda de espaços paisagísticos. Rio de Janeiro: Fundação Casa de Rui Barbosa, 2014. pp.254-267. 
BELÉM, Celica Isaura Fernandes; COSTA, Nara Leane; MELLO, Paulo Quintanilha Nobre de; OLIVEIRA, Ronaldo Fernandes de; LAROCHE, Rose Claire Maria. O Campo de Santana. Rodriguésia, Rio de Janeiro, vol. XXXII, n. 55, 1980. pp.407-414.

BRUNO, Ernani Silva. Histórias e Tradições da Cidade de São Paulo. São Paulo: José Olympio, 1953. 3 v. Disponível em: <https://goo.gl/Eb9xc6>. Acesso em: 01 nov. 2016.

CALDEIRA, Júnia. A Praça Brasileira: trajetória de um espaço urbano-origem e modernidade. Tese (Doutorado) - IFCH/Unicamp, Campinas, 2007.

CAMPOS, Eudes. Arquitetura paulistana sob o Império. Tese (Doutorado) - FAU/USP, São Paulo, 1997 [edição revista e ampliada]. Disponível em: <www.arquipaulistana.com/tese>. Acesso em: 01 fev. 2017.

DOURADO, Guilherme Mazza. Belle Époque dos Jardins: da França ao Brasil do século XIX e início do XX. Tese (Doutorado) - FAU/USP, São Paulo, 2009.

GOMBRICH, Ernst. A história da arte. São Paulo: Martins Fontes, 1998.

KLIASS, Rosa Grena. Os parques urbanos de São Paulo. São Paulo: Pini, 1993.

MAGALHÃES, Cristiane Maria; MARQUES, Teresa. Técnica, arte e cultura nos jardins de meados de oitocentos até ao limiar do século XX, em Portugal e no Brasil. In: Anais do I Congresso internacional de história da construção luso-brasileira. Vitória: UFES, 2013. CD-Room.

Francisco da Silva Reis - arte, técnica e natureza. Disponível em: <https://goo.gl/ rrVO8q>. Acesso em: 01 fev. 2017.

O desenho da bistória no traço da paisagem: patrimônio paisagístico e jardins bistóricos no Brasil - memória, inventário e salvaguarda. Tese (Doutorado) - IFCH/Unicamp, Campinas, 2015. Disponível em: <https://goo.gl/42Apru>. Acesso em: 7 jul. 2017.

MARQUES, Teresa. Dos jardineiros paisagistas e borticultores do Porto de Oitocentos ao modernismo na arquitectura paisagista em Portugal. Tese (Doutorado) - Instituto Superior de Agronomia, Universidade Técnica de Lisboa, Lisboa, 2009.

MUMFORD, Lewis. A cidade na história: suas origens, transformações e perspectivas. 3. ed. São Paulo: Martins Fontes, 1991.

OLIVEIRA, Eustáquio Gorgone. Jardins esquecidos. Caxambu: [s.n.], [s.d]. Disponível em: <https://goo.gl/p1SAFR> (consulado em 5 outubro de 2017). 
PIGNATELLI, Ignácio Nuno. Cascateiros de Avintes criadores de pequenos mundos. Porto: Centro Regional de Artes Tradicionais, 1996.

RACINE, Michel. Jardins au naturel: rocailles, grotesques et art rustique. Paris: Actes Sud, 2001.

RIBEIRO, Nelson Porto. A natureza reconstruída: o sublime nos jardins cariocas do século XIX. In: Anais do Colóquio Ibero-Americano: Paisagem Cultural, Patrimônio e Projeto 3. Belo Horizonte: UFMG, 2014. Disponível em : <https://goo.gl/1YmLdJ> (consultado em 1 de fevereiro de 2017).

SCHAVEIZON, Daniel. El árbol de cemento: arquitecturas desaparecidas, grutas y rocallas. Seminario de Crítica - Año 2014, Buenos Aires: Instituto de Arte Americano e Investigaciones Estéticas (UBA), n. 192, 27 jun. 2014.

TERRA, Carlos. O jardim no Brasil no século XIX: Glaziou revisitado. Rio de Janeiro: EBA/UFRJ, 2000.

Paisagens construídas: jardins, praças e parques do Rio de Janeiro na segunda metade do século XIX. Rio de Janeiro: Rio Books, 2013.

Artigo apresentado em 28/11/2016. Aprovado em 17/06/2017

All the contents of this journal, except where otherwise noted, is licensed under a Creative Commons Attribution License

\section{(cc) BY}

